University of New Hampshire

University of New Hampshire Scholars' Repository

Faculty Publications

$2-1-2005$

\title{
Fine root dynamics and trace gas fluxes in two lowland tropical forest soils
}

Whendee L. Silver

University of California, Berkeley

Andrew W. Thompson

University of California, Berkeley

Megan E. McGroddy

University of California, Berkeley

Ruth K. Varner

University of New Hampshire, Durham, ruth.varner@unh.edu

Jadson D. Dias

Escola de Agricultural Luiz Queiroz

See next page for additional authors

Follow this and additional works at: https://scholars.unh.edu/faculty_pubs

\section{Comments}

This article was written and prepared by U.S. Government employees on official time, and is therefore in the public domain. It was published by Wiley in Global Change Biology in 2005, available online: https://dx.doi.org/10.1111/

j.1365-2486.2005.00903.x

\section{Recommended Citation}

Silver, W. L., A.W. Thompson, ${ }^{\circ}$ M. McGroddy, R.K. Varner, J.D. Dias, ${ }^{\circ} \mathrm{H}$. Silva, P.M. Crill, and M. Keller (2005), Fine root dynamics and trace gas fluxes in two lowland tropical forest soils, Global Change Biol.,11,2.

This Article is brought to you for free and open access by University of New Hampshire Scholars' Repository. It has been accepted for inclusion in Faculty Publications by an authorized administrator of University of New Hampshire Scholars' Repository. For more information, please contact Scholarly.Communication@unh.edu. 


\section{Authors}

Whendee L. Silver, Andrew W. Thompson, Megan E. McGroddy, Ruth K. Varner, Jadson D. Dias, Hudson Silva, Patrick M. Crill, and Michael Keller 


\title{
Fine root dynamics and trace gas fluxes in two lowland tropical forest soils
}

\author{
WHENDEE L. SILVER*, ANDREW W. THOMPSON*, MEGAN E. MCGRODDY*1, \\ RUTHK. VARNER $\dagger$, JADSON D. DIAS $\ddagger^{2}$, HUDSON SILVA $\dagger+$ PATRICK M. CRILL $\dagger^{3}$ \\ and MICHAEL KELLER \\ *Division of Ecosystem Sciences, Department of Environmental Science, Policy, and Management, University of California, \\ Berkeley, CA, USA, 151 Hilgard Hall \#3110, CA 94720, †Complex Systems Research Center, Institute for the Study of Earth Oceans \\ and Space, University of New Hampshire, Durham, NH, USA, †Fundacao Floresta Tropical, Santarem, Para, Brazil, §USDA Forest \\ Service, International Institute of Tropical Forestry, Rio Piedras, Puerto Rico
}

\begin{abstract}
Fine root dynamics have the potential to contribute significantly to ecosystem-scale biogeochemical cycling, including the production and emission of greenhouse gases. This is particularly true in tropical forests which are often characterized as having large fine root biomass and rapid rates of root production and decomposition. We examined patterns in fine root dynamics on two soil types in a lowland moist Amazonian forest, and determined the effect of root decay on rates of $\mathrm{C}$ and $\mathrm{N}$ trace gas fluxes. Root production averaged $229( \pm 35)$ and $153( \pm 27) \mathrm{g} \mathrm{m}^{-2} \mathrm{yr}^{-1}$ for years 1 and 2 of the study, respectively, and did not vary significantly with soil texture. Root decay was sensitive to soil texture with faster rates in the clay soil $\left(k=-0.96\right.$ year $\left.^{-1}\right)$ than in the sandy loam soil $\left(k=-0.61\right.$ year $\left.^{-1}\right)$, leading to greater standing stocks of dead roots in the sandy loam. Rates of nitrous oxide $\left(\mathrm{N}_{2} \mathrm{O}\right)$ emissions were significantly greater in the clay soil $\left(13 \pm 1 \mathrm{ng} \mathrm{N} \mathrm{cm}^{-2} \mathrm{~h}^{-1}\right.$ ) than in the sandy loam $\left(1.4 \pm 0.2 \mathrm{ng} \mathrm{N} \mathrm{cm}^{-2} \mathrm{~h}^{-1}\right)$. Root mortality and decay following trenching doubled rates of $\mathrm{N}_{2} \mathrm{O}$ emissions in the clay and tripled them in sandy loam over a 1-year period. Trenching also increased nitric oxide fluxes, which were greater in the sandy loam than in the clay. We used trenching (clay only) and a mass balance approach to estimate the root contribution to soil respiration. In clay soil root respiration was $264-380 \mathrm{~g} \mathrm{C} \mathrm{m}^{-2} \mathrm{yr}^{-1}$, accounting for $24 \%$ to $35 \%$ of the total soil $\mathrm{CO}_{2}$ efflux. Estimates were similar using both approaches. In sandy loam, root respiration rates were slightly higher and more variable $\left(521 \pm 206 \mathrm{~g} \mathrm{C} \mathrm{m}^{2} \mathrm{yr}^{-1}\right)$ and contributed $35 \%$ of the total soil respiration. Our results show that soil heterotrophs strongly dominate soil respiration in this forest, regardless of soil texture. Our results also suggest that fine root mortality and decomposition associated with disturbance and land-use change can contribute significantly to increased rates of nitrogen trace gas emissions.
\end{abstract}

Keywords: carbon dioxide, methane, nitric oxide, nitrous oxide, root decomposition, root productivity, root respiration, root turnover

Received 24 October 2003; revised version received 9 April 2004; accepted 10 September 2004

Correspondence: Whendee L. Silver, tel. + 1 510-643-3074,

fax + 1 510-643-5098, e-mail: wsilver@nature.berkeley.edu

${ }^{1}$ Present address: EEB Department, Princeton University,

Princeton, NJ, USA.

${ }^{2}$ Present address: Escola de Agricultural Luiz Queiroz, Piracicaba, SP 13416-000, Brazil.

${ }^{3}$ Present address: Department of Geology and Geochemistry, Stockholm University, Stockholm 106 91, Sweden.
Introduction

Root production and decomposition represent important fluxes of photosynthetically derived carbon (C) in terrestrial ecosystems, influencing the total standing stocks and turnover time of $\mathrm{C}$ in soils. Root dynamics also have the potential to influence the production and emission of radiatively active trace gases. Live roots respire carbon dioxide $\left(\mathrm{CO}_{2}\right)$, and both live and dead roots contribute labile $\mathrm{C}$ and nitrogen $(\mathrm{N})$ to fuel 
microbial production of $\mathrm{CO}_{2}$, nitrous oxide $\left(\mathrm{N}_{2} \mathrm{O}\right)$, nitric oxide (NO), and methane $\left(\mathrm{CH}_{4}\right)$. Tropical forests have among the largest root biomass, highest rates of fine root productivity (Vogt et al., 1986, 1996) and fastest root decay rates (Silver \& Miya, 2001) for forest ecosystems globally. Tropical forests are also the largest natural source of soil $\mathrm{CO}_{2}$ (Raich \& Schlesinger, 1992) and $\mathrm{N}_{2} \mathrm{O}$ (Bouwman et al., 1993; Prather et al., 1995). NO is a precursor of tropospheric ozone and even the low rates produced in tropical forests such as the Amazon are thought to play an important role in the regulation of atmospheric oxidant production (Keller et al., 1991; Chameides et al., 1992; Rummel et al., 2002). Upland tropical forest soils are generally considered a net sink for atmospheric $\mathrm{CH}_{4}$, but changes in land use and cover type can decrease the strength of this sink (Keller et al., 1990, 1993).

There are several ways in which the large biomass and high rates of growth and decomposition of fine roots in tropical forests may influence the type and rates of trace gas emissions. High root biomass and production should result in high rates of root respiration and the associated microbial respiration intimately coupled with live roots in the rhizosphere (Högberg et al., 2002). Rapid rates of root turnover and decay provide substrate for heterotrophic respiration. Decomposition can also stimulate $\mathrm{N}$ mineralization and nitrification (Chen et al., 2002), leading to greater potential for losses of $\mathrm{NO}$ and $\mathrm{N}_{2} \mathrm{O}$ from soils. Several environmental and physiological factors contribute to patterns in root biomass, growth, and decomposition (Vogt et al., 1986; Jackson et al., 1990; Silver \& Miya, 2001). Soil texture has been shown to be a good indicator of several soil and microclimatic conditions that influence roots including soil nutrient availability, water availability, and aeration (Cuevas \& Medina, 1986, 1988; Silver et al., 2000; McGroddy, 2002). In a moist, lowland tropical forest, sandy soils exhibited more fine root biomass, lower water holding capacity, lower potential $\mathrm{N}$ fluxes, and greater soil $\mathrm{P}$ availability relative to clay soils (Silver et al., 2000).

Although there is a strong theoretical link between fine root and trace gas dynamics, there are relatively few studies that have examined these relationships quantitatively. Fine root mortality has been found to increase nitrogen oxide emissions from tropical forest soils over short time periods (Matson et al., 1990; Keller et al., 2000; Varner et al., 2003), but the longer term effects of root decomposition have not been explored. Similarly there are few estimates of root respiration and the relative contributions of roots and nonrhizosphere heterotrophs to soil $\mathrm{CO}_{2}$ efflux in tropical forests. Soil respiration is largely derived from a combination of roots and heterotrophs. Knowing the relative impor- tance of these two contributors to soil respiration is critical to understanding the components of net ecosystem production and ecosystem $\mathrm{C}$ balance.

In this study, we measured fine root dynamics, $\mathrm{N}$ pools and cycling, and trace gas effluxes in a lowland moist Amazonian forest on two soil textural types. Previous work at this site documented the large and important role of soil texture in patterns of fine and coarse root biomass and distribution, patterns in the pool size and turnover of soil C, and pools and potential fluxes of N and P (Silver et al., 2000; Telles et al., 2003; McGroddy et al., 2004). For this study, our goals were to determine how rates of production and decomposition of fine roots differ by soil texture, how root decay influences mineral $\mathrm{N}$ pools and fluxes, how root decomposition influences trace gas production, and the relative contribution of roots to soil respiration in clay and sandy loam soils.

\section{Methods}

\section{Site description and experimental design}

The study was conducted in the Tapajos National Forest (TNF) located $50 \mathrm{~km}$ south of Santarem, Para, Brazil $\left(2^{\circ} 64^{\prime} \mathrm{S}\right.$ and $\left.54^{\circ} 59^{\prime} \mathrm{W}\right)$, and is being studied as part of the Brazilian-led Large-Scale Biosphere-Atmosphere Experiment in Amazonia. The region has a mean annual temperature of $25^{\circ} \mathrm{C}$ and receives approximately $2000 \mathrm{~mm}$ of rain per year with a dry season lasting from July to December (Parrotta et al., 1995). The 1000 ha study site was located on an old, nearly flat, erosional remnant plateau (planalto) with a very limited surficial drainage network formed on sediments of the Barreiras formation. Soils are deep and highly weathered with dominantly sandy or clayey texture. Approximately $68 \%$ of the study area is on clays or clay loams (Ultisols and Oxisols) and 32\% on sands and sandy loams (Ultisols) (Silver et al., 2000). The vegetation is evergreen, mature tropical forest with a total biomass of approximately $372 \mathrm{Mg} \mathrm{ha}^{-1}$ (Keller et al., 2001).

In 1999 , six plots approximately $4 \mathrm{~m} \times 12 \mathrm{~m}$ in size were randomly located in closed canopy forest, with three plots each on clay (approximately 60\% clay) and sandy loam soils (approximately $80 \%$ sand). Plots within a given textural class were within $100 \mathrm{~m}$ of each other; clay and sandy loams were within approximately $1 \mathrm{~km}$ of each other in continuous forest. Plots were sampled every other month for fine root biomass from July 5, 1999 to May 5, 2000. In June 2000, we increased our sample size to five control plots on clay and sandy loam that were paired with five randomly selected trench plots. We used trenched plots to estimate rates of 
fine root decomposition and the root contribution to soil respiration. Trench plots were located away from the bases of large trees to minimize the impact of coarse roots. Trench plots were constructed by digging around a $2.5 \mathrm{~m} \times 2.5 \mathrm{~m}$ block of land to $1 \mathrm{~m}$ depth, lining the trenches with stainless-steel screening (pore openings $<0.5 \mathrm{~mm}$ ), and then backfilling the trenches. All live vegetation was removed from the isolated blocks of land, and the plots were kept free of regrowth by weeding (Silver \& Vogt, 1993).

\section{Root production, turnover, and decomposition}

All root data reported here are for the $\leq 2 \mathrm{~mm}$ diameter root fraction. We used the sequential coring method to estimate changes in live fine root (LFR) and dead fine root (DFR) standing stocks over time (Vogt \& Persson, 1991). In the control plots, three replicate cores were sampled from the 0 to $10 \mathrm{~cm}$ depth using a $6 \mathrm{~cm}$ diameter corer every other month for 2 years (July 1999 to May 2001). Roots were hand sorted into live and dead categories using visual characteristics and tensile strength (Vogt \& Persson, 1991), dried at $65^{\circ} \mathrm{C}$, and weighed to determine mass. Root decomposition was estimated in the trench plots. Trench plots were sampled five times between June 2000 and July 2001 using the methods described above. Root production was estimated for each year using the compartment flow model (Santantonio \& Grace, 1987; Publicover \& Vogt, 1993; Ostertag, 2001):

$$
\begin{aligned}
P_{t} & =\left(\mathrm{LFR}_{t}-\mathrm{LFR}_{t-1}\right)+\left(\mathrm{DFR}_{t}-\mathrm{DFR}_{t-1}\right)+M_{\mathrm{d} t}, \\
M_{\mathrm{d} t} & =\operatorname{DSS}\left(1-\exp ^{(-k t)}\right),
\end{aligned}
$$

where $P_{t}$ is fine root productivity, LFR is live fine root mass at time $t$ and $t-1, \mathrm{DFR}$ is dead fine root mass at time $t$ and $t-1, M_{\mathrm{d} t}$ is the mass of roots decayed over the interval, and DSS is the mean DFR standing stock over the interval. The compartment flow model estimates annual production as the sum of the change in live and dead root biomass between the initial and final sampling point, and the mass decomposed over the interval. Only statistically significant differences in live and dead root biomass are considered. This method is more accurate than other methods under conditions of overlapping periods of production and mortality (likely in an evergreen tropical forest) because it considers these factors explicitly. It is also relatively insensitive to the length of intervals between sampling (Publicover \& Vogt, 1993). We used mean values from each plot ( $n=$ three cores per plot per date) for initial and final LFR and DFR biomass per year. The mass of roots decomposed was determined by multiplying the mean dead standing stock of fine roots per plot over the interval by $1-\exp ^{-k t}$ where $k$ is the decay constant and $t$ is time. We used the decay constant generated from the trench plots in year 2 for calculating production in both years.

Root decomposition was estimated using the change in fine root necromass over time in the trench plots, and was modeled as a first-order decay process $\left(y=\mathrm{e}^{-k t}\right)$. Decay rates are expressed as $k$ in years ${ }^{-1}$. We used the $k$ values from the trench plot experiments applied to the mass of dead roots in the control plots. Because trench plot data were only available for the second year of the study, we used the same $k$ value for both years, which represents a potential source of error in our estimates. Root turnover was defined as root productivity divided by the maximum annual standing stock of fine roots for that year (Gill \& Jackson, 2000). We calculated the C allocation to fine roots as $50 \%$ of root production. The average $\mathrm{C}$ input to the soil via root turnover was estimated by multiplying root productivity for a given year by the turnover rate for that year, assuming that biomass was $50 \% \mathrm{C}$. We estimated the balance between total root inputs to soil and root decay during year 2 . Roots inputs were calculated by multiplying fine root turnover by the maximum standing stock of roots for that year. Roots lost via decay were estimated as

$$
\operatorname{Root}_{\mathrm{L}}=\operatorname{Root}_{\mathrm{ms}}-\left(\operatorname{Root}_{\mathrm{ms}} \exp ^{(-k t)}\right)
$$

where $\operatorname{Root}_{\mathrm{L}}$ is the mass of roots lost in $\mathrm{g} \mathrm{m}^{-2} \mathrm{yr}^{-1}$, and Root $_{\mathrm{ms}}$ is the maximum standing stock of fine roots for that year.

\section{Root chemical characteristics}

Root C chemistry was measured using sequential extractions (Ryan et al., 1989) at the Center for Water and the Environment of the Natural Resources Research Institute, University of Minnesota, Duluth, MN. One bulked root sample was used per plot and date. The $\mathrm{C}$ fractions measured were nonpolar extractives, water soluble and acid soluble extracts, tannins, and water and acid soluble fractions expressed as glucose equivalents. Lignin was determined as the difference between the whole sample and the sum of the nonpolar extractives, and water and acid soluble fractions. Total $\mathrm{C}$ and $\mathrm{N}$ were measured on a $\mathrm{CN}$ analyzer (CE Elantec, Lakewood, NJ, USA) at UC Berkeley. All root data are expressed on an oven dry equivalent, ash-free basis.

\section{Trace gases}

The fluxes of $\mathrm{CO}_{2}, \mathrm{~N}_{2} \mathrm{O}, \mathrm{NO}$, and $\mathrm{CH}_{4}$ were sampled weekly in trenched and control plots for the first 10 weeks and are reported in Varner et al. (2003). The goal of these short-term measurements was to isolate the effects of initial root mortality on trace gas fluxes. In 
this study, we determined the impact of root decomposition and the absence of live root biomass on trace gas fluxes, and compared these with the effects of initial root mortality. Using the same plots we sampled $\mathrm{N}_{2} \mathrm{O}$ and $\mathrm{CH}_{4}$ monthly for 11 additional months until July 2001. $\mathrm{CO}_{2}$ and $\mathrm{NO}$ were sampled monthly for 5 additional months and then every 2.5 months thereafter until May 2001. For $\mathrm{N}_{2} \mathrm{O}$ and $\mathrm{CH}_{4}$ measurements we used two $25 \mathrm{~cm}$ diameter PVC rings per plot inserted approximately $2 \mathrm{~cm}$ into the soil before each sampling period. Molded PVC Chamber tops were fitted over the rings prior to sampling. $\mathrm{CO}_{2}$ and $\mathrm{NO}$ were measured in the field with a dynamic flow chamber and analyzed for $\mathrm{CO}_{2}$ on a Li-Cor 6262 infrared gas analyzer (Li-Cor Biosciences, Lincoln, NE, USA) and for $\mathrm{NO}$ on a Scintrex LMA-3 chemiluminescent analyzer (Scintrex, Concord, Ont., Canada). NO was measured after conversion to $\mathrm{NO}_{2}$ using a $\mathrm{CrO}_{3}$ catalyst. $\mathrm{N}_{2} \mathrm{O}$ and $\mathrm{CH}_{4}$ were sampled using a static chamber and samples were analyzed within $36 \mathrm{~h}$ of collection in Santarem (Para, Brazil) using electron capture $\left(\mathrm{N}_{2} \mathrm{O}\right)$ and flame ionization $\left(\mathrm{CH}_{4}\right)$ detection gas chromatographs (Shimadzu Scientific Instruments, Columbia, MD, USA).

\section{Soil characterization}

Detailed soil characteristics are presented in Silver et al. (2000). For this study, we measured gravimetric soil moisture, soil temperature, soil $\mathrm{N}$ pools, and net $\mathrm{N}$ mineralization and nitrification rates from trench plots and controls during the second year of the study. Soil moisture was sampled in close proximity to the surface flux chambers using three $2.5 \mathrm{~cm} \times 10 \mathrm{~cm}$ deep soil cores. Samples were collected during 15 dates (all but four of the trace gas sampling periods). Soils were dried at $105^{\circ} \mathrm{C}$ until reaching a constant weight and then weighed to determine moisture loss. Water-filled pore space (WFPS) was estimated from soil moisture and porosity (porosity $=1$-bulk density/particle density) for trench plots and controls. Bulk density values were taken from Silver et al. (2000) and particle density was assumed to be $2.65 \mathrm{~g} \mathrm{~cm}^{-3}$. Soil $\mathrm{N}$ pools were determined on fresh samples $(0-10 \mathrm{~cm}$ depth) during the five dates that we sampled the trench plots for root biomass. We took three replicate samples per plot with a $2.5 \mathrm{~cm}$ diameter corer to $10 \mathrm{~cm}$ depth $(n=20$ plots and 60 samples per time period). Soils were extracted with $2 \mathrm{M}$ $\mathrm{KCl}$ the same day of collection. Soil extract $\mathrm{N}$ concentrations were determined at U.C. Berkeley on a Lachat QC 8000 autoanalyzer (Lachat Instruments, Loveland, CO, USA). Net $\mathrm{N}$ mineralization and nitrification rates were estimated for the first three measurement periods according to Hart et al. (1994).

\section{Root respiration}

We estimated the contribution of live roots to total soil respiration using the following equations:

$$
\begin{gathered}
R_{\text {root }}=R_{\text {total }}-R_{\text {soil }}-R_{\text {decay }}, \\
R_{\text {soil }}=R_{\text {trench }}-R_{\text {Tdecay }},
\end{gathered}
$$

where $R_{\text {root }}$ is root respiration, $R_{\text {total }}$ is total soil respiration in control plots estimated from data interpolation and summing for the study period, $R_{\text {soil }}$ is nonroot soil respiration derived from fine litter and soil organic matter, and $R_{\text {decay }}$ is root C lost via decomposition using the first-order decay model from the trench plot experiment applied to initial biomass of the treatment or control plot. $R_{\text {soil }}$ was estimated as the difference between the trench plot soil respiration $\left(R_{\text {trench }}\right)$ and the root $C$ lost via decomposition in the trench plot $\left(R_{\text {Tdecay }}\right)$ over the study period. We estimated $R_{\text {Tdecay }}$ and $R_{\text {decay }}$ for the $0-10 \mathrm{~cm}$ depth by applying trench plot $k$ values to the initial treatment or control root biomass. We applied the same $k$ value to a mean fine root biomass value for the $10-40 \mathrm{~cm}$ depth reported for the same soils in Silver et al. (2000). Because decay rates are likely to decrease with depth, using the $0-10 \mathrm{~cm}$ decay constant is likely to result in a slight overestimate of the root contribution to total soil respiration. One of the uncertainties in estimating the contribution of decaying roots to soil $\mathrm{CO}_{2}$ efflux is the amount of root material converted to soil organic matter and the amount released via microbial respiration. We bracketed our root respiration estimate by assuming 100\% conversion of decayed fine roots to $\mathrm{CO}_{2}$ (low estimate) or no contribution of $\mathrm{CO}_{2}$ from root decay (high estimate). Both estimates represent extreme conditions, and thus actual root respiration should lie somewhere between the two extremes.

We performed sensitivity analyses to determine the effects of two potential sources of error in our estimates. First, we examined the effect of underestimating the root $C$ contribution to decay. This could occur if our decay coefficient for deeper roots was unrealistically high and/or if roots deeper than $40 \mathrm{~cm}$ were an important source of $\mathrm{CO}_{2}$. We also determined the effect of an over- or underestimation of soil $\mathrm{CO}_{2}$ flux. We performed a sensitivity analysis by systematically decreasing the decay constant $k$ by $50 \%$ for roots in the $10-40 \mathrm{~cm}$ depth, by increasing the root $\mathrm{C}$ lost via decay by $50 \%$, and/or by increasing or decreasing the soil $\mathrm{CO}_{2}$ flux by $25 \%$.

We compared the above measure of the root contribution to soil respiration to a measure of root respiration determined from a mass balance approach:

$$
R_{\text {root }}=\left(1-\left(\frac{\sum \text { Inputs }}{R_{\text {total }}}\right)\right) R_{\text {total }}
$$


where inputs include above- and belowground fine litter inputs over the study period. We used litterfall inputs collected from nearby plots on sandy loam and clay soils, and fine root production and turnover estimates from control sites. Fine litterfall was measured in the control sites using six $900 \mathrm{~cm}^{2}$ circular baskets per plot. Litter was collected every 2 weeks during the study period, dried at $65^{\circ} \mathrm{C}$, sorted into six fractions (leaves, fruits and flowers, fine wood, coarser wood (1-5 cm diameter), insects, and miscellaneous material) and weighed to determine mass. Here we report the total fine litterfall data (i.e. the sum of the six fractions). C content of fine litterfall was assumed to be $50 \%$ of the mass. Belowground litter inputs $(0-40 \mathrm{~cm}$ depth) were estimated by multiplying the standing stock of fine roots by the root turnover values for the $0-10 \mathrm{~cm}$ depth.

\section{Statistical analyses}

We used Systat 10 (SPSS, 2000) to examine patterns in root biomass, root chemistry, soil $\mathrm{N}$ pools and fluxes, and trace gas fluxes. We used mean values per plot for each variable. Differences between soil textural classes were tested using analysis of variance (ANOVA), and among sampling dates using repeated measures ANOVA. Data were log transformed where appropriate to meet the assumptions of ANOVA. We used the least-significant difference protocol as a means separation test. We used regression analyses to explore correlations among two or more variables. Significance was determined at the 95\% level unless otherwise noted.

\section{Results}

\section{Root biomass, productivity, and turnover}

Total fine root biomass $(0-10 \mathrm{~cm}$ depth $)$ averaged $218 \pm 11 \mathrm{~g} \mathrm{~m}^{-2}$ in clay plots over the 2-year study and was $292 \pm 11 \mathrm{~g} \mathrm{~m}^{-2}$ in the sandy loam plots $(P<0.01)$, and remained relatively constant over time. On average, total fine root biomass was slightly greater in year 1 than in year $2(P=0.06$, Table 1$)$. The proportion of LFR and DFR varied significantly over the year in both clay and sandy loam (Fig. 1). Fine live root biomass was significantly greater the second year of the study, while dead root biomass was greatest in year 1 (Table 1). There was significantly less fine live root biomass than dead root biomass at most sampling periods (Fig. 1), and live root biomass remained low from the late dry season of 1999 until September 2000. This followed a particularly dry period (July-September 1999) which may have affected both surface root growth and survival. Fine root productivity averaged
Table 1 Fine root biomass $\left(\mathrm{g} \mathrm{m}^{-2}\right)$, root productivity $\left(\mathrm{g} \mathrm{m}^{-2} \mathrm{yr}^{-1}\right)$, turnover (year $\left.{ }^{-1}\right)$, and the decay constant $k$ $\left(\right.$ year $^{-1}$ ) in clay and sandy soil of the Tapajos National Forest (Para, Brazil)

\begin{tabular}{|c|c|c|c|c|}
\hline & \multicolumn{2}{|r|}{ Clay } & \multicolumn{2}{|c|}{ Sand } \\
\hline \multicolumn{5}{|c|}{ July 1999 to May 2000} \\
\hline Live & \multicolumn{3}{|c|}{$40 \pm 10$} & $48 \pm 14$ \\
\hline Dead & \multicolumn{2}{|r|}{$206 \pm 19$} & \multicolumn{2}{|r|}{$248 \pm 14$} \\
\hline Total & \multicolumn{2}{|r|}{$244 \pm 18$} & \multicolumn{2}{|r|}{$296 \pm 17$} \\
\hline Productivity & \multicolumn{2}{|r|}{$204 \pm 22$} & \multicolumn{2}{|r|}{$254 \pm 72$} \\
\hline Turnover & \multicolumn{2}{|r|}{$0.70 \pm 0.14$} & \multicolumn{2}{|r|}{$0.57 \pm 0.08$} \\
\hline \multicolumn{5}{|c|}{ June 2000 to May 2001} \\
\hline Live & \multicolumn{2}{|r|}{$53 \pm 7$} & \multicolumn{2}{|r|}{$52 \pm 6$} \\
\hline Dead & \multicolumn{2}{|r|}{$148 \pm 12$} & \multicolumn{2}{|r|}{$237 \pm 14$} \\
\hline Total & \multicolumn{2}{|r|}{$201 \pm 13$} & \multicolumn{2}{|r|}{$289 \pm 15$} \\
\hline Productivity & \multicolumn{2}{|r|}{$157 \pm 22$} & \multicolumn{2}{|r|}{$149 \pm 54$} \\
\hline Turnover & \multicolumn{2}{|r|}{$0.69 \pm 0.1$} & \multicolumn{2}{|r|}{$0.39 \pm 0.12$} \\
\hline \multirow[t]{2}{*}{$k^{*}$} & \multicolumn{2}{|r|}{$-0.96 \pm 0.10$} & \multicolumn{2}{|r|}{$-0.61 \pm 0.15$} \\
\hline & $n$ & $\mathrm{df}$ & $F$ statistic & $P$ \\
\hline \multicolumn{5}{|l|}{ By texture } \\
\hline Dead & 96 & 1 & 23.9 & 0.00 \\
\hline Total & 96 & 1 & 20.9 & 0.00 \\
\hline$k$ & 10 & 1 & 4.1 & 0.08 \\
\hline \multicolumn{5}{|l|}{ By year } \\
\hline Live & 96 & 1 & 6.53 & 0.01 \\
\hline Dead & 96 & 1 & 7.40 & 0.01 \\
\hline Total & 96 & 1 & 3.53 & 0.06 \\
\hline Turnover & 16 & 1 & 3.34 & 0.09 \\
\hline
\end{tabular}

Values are means and standard errors. ANOVA tables show where statistically significant differences occurred in texture and sampling year. There were no significant interaction terms.

*Only measured in year 2 .

$229( \pm 35) \mathrm{g} \mathrm{m}^{-2} \mathrm{yr}^{-1}$ in year 1 and was slightly greater than in year $2\left(153 \pm 27 \mathrm{~g} \mathrm{~m}^{-2} \mathrm{yr}^{-1} ; P=0.06\right)$. There were no statistically significant trends with texture (Table 1). These values correspond to a rate of $\mathrm{C}$ allocation to fine roots of approximately 77$115 \mathrm{~g} \mathrm{C} \mathrm{m}^{-2} \mathrm{yr}^{-1}$. Turnover of fine roots was also very similar on the two soil types, but rates were faster in year $1\left(0.69 \pm 0.08\right.$ year $\left.^{-1}\right)$ than in year $2(0.48 \pm 0.07$ year $\left.{ }^{-1}\right)$, because of a decrease in turnover rates in year 2 in the sandy loam. These turnover rates contributed approximately $37-79 \mathrm{~g} \mathrm{C} \mathrm{m}^{-2} \mathrm{yr}^{-1}$ of fine root biomass to the soil.

Root decomposition, root secondary chemistry, and soil characteristics

Total fine root mass declined over time in the trench plots, but did not change significantly over time in 
(a)

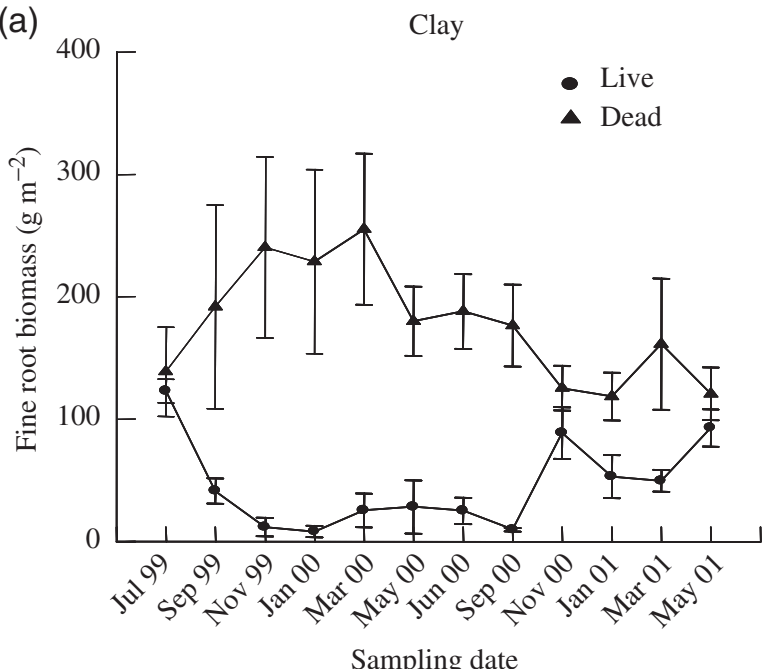

(b)

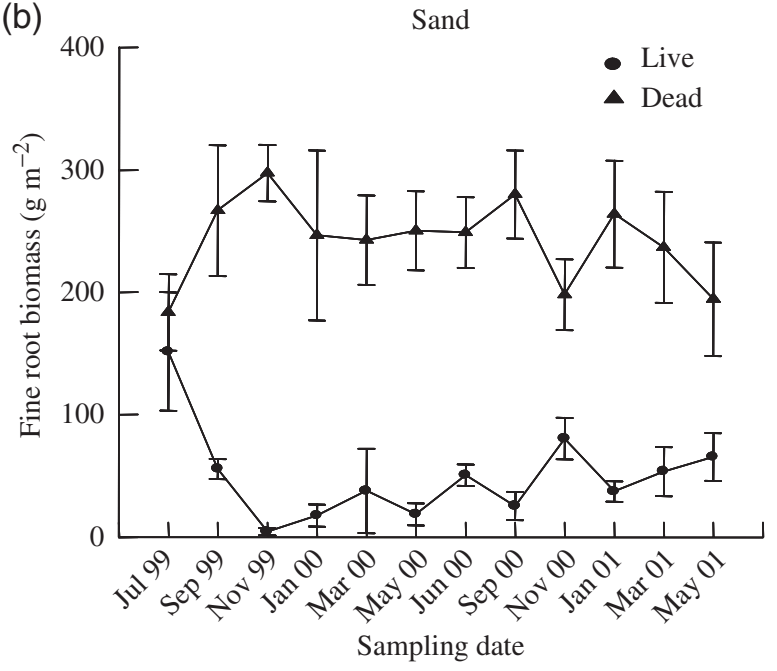

Fig. 1 Patterns in live and dead fine root biomass $\left(\mathrm{g} \mathrm{m}^{-2}\right)$ in the $0-10 \mathrm{~cm}$ soil depth on clay (a) and sandy loam (b) soils in the Tapajos National Forest (Para, Brazil). Values are means and standard errors. Three cores were taken per plot and three to five plots were sampled every other month in both clay and sandy loam soils.

controls (Fig. 2). There was less fine root mass in clay soils than in sandy loam in both trenched and control plots $(P<0.05)$, and root decomposition was faster $(P=0.08)$ in clay soil $(k=-0.96 \pm 0.10)$ than in sandy loam $(k=-0.61 \pm 0.15)$. Patterns of fine root mass loss over time differed in clay and sandy loam (Fig. 2). In clay soils, root biomass declined significantly 5 months after isolation, and continued to decline until month 9 (March 2001). Root biomass in sandy loam soil also decreased 5 months after trenching, and then again at the end of the experiment, 13 months after trench plot establishment. At the end of experiment there was $36 \pm 6 \%$ fine root mass remaining in the clay soil and
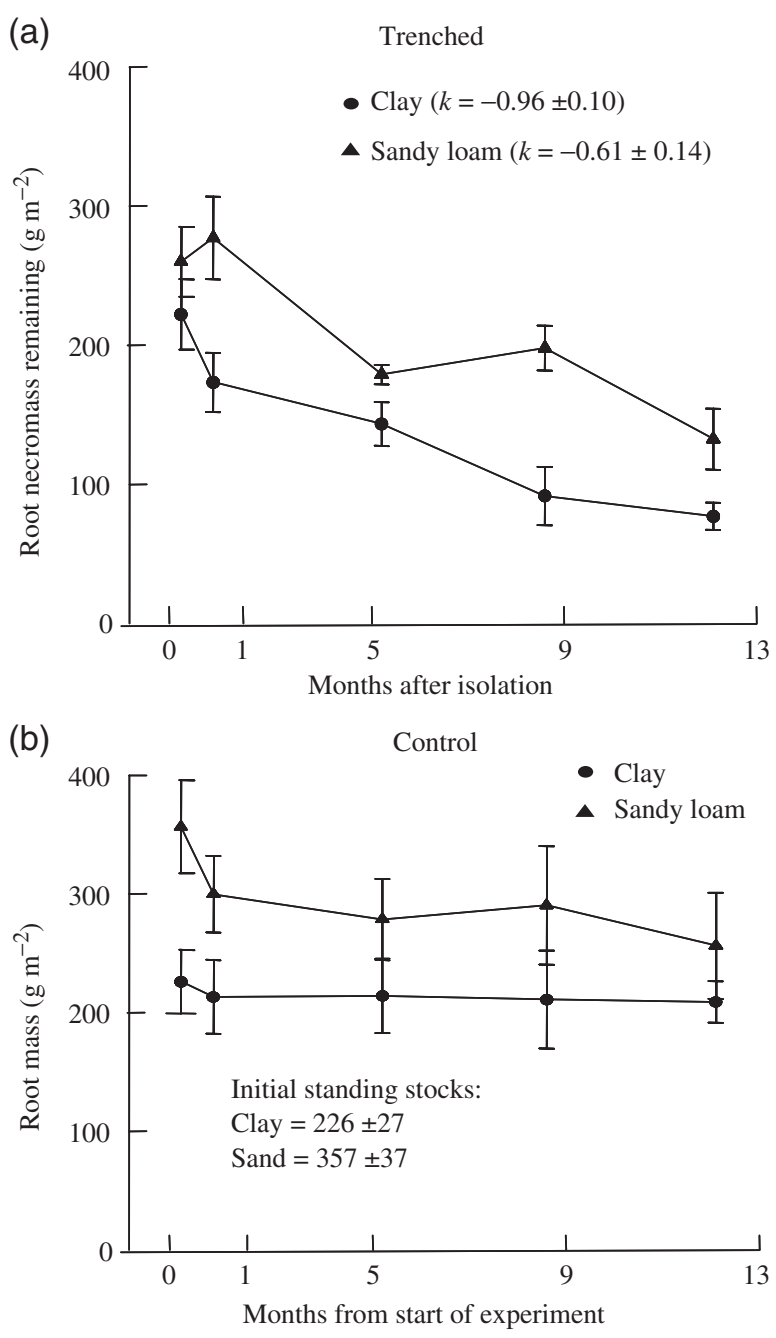

Fig. 2 Total fine root mass over time $(0-10 \mathrm{~cm}$ depth $)$ in trenched and control plots on clay and sandy loam soils in the Tapajos National Forest (Para, Brazil). In trenched plots (a) root necromass was followed during decay. The decomposition constant $k$ is given in parentheses. In controls (b), total fine root standing stocks (live plus dead) were sampled. Values are means and standard errors of three cores per plot and five plots per treatment and soil texture type.

$52 \pm 9 \%$ remaining in the sandy loam. Roots in clay soil had significantly higher concentrations of nonpolar extractives and acid soluble $\mathrm{C}$ and glucose equivalents, but were lower in total $C$ and lignin than roots in sandy loam. Roots in sandy loam also had higher lignin: N ratios (Table 2). There were few patterns over time in root secondary chemistry, and root decomposition was not correlated with $\mathrm{C}$ chemistry, or the lignin: $\mathrm{N}$ or $\mathrm{C}: \mathrm{N}$ ratios.

WFPS averaged $0.65( \pm 0.01) \%$ in both clay control and trench plots. In the sandy loam, mean annual WFPS was significantly higher in the trench plots 
Table 2 Percent ash, secondary compounds, carbon, nitrogen, and the carbon : nitrogen and lignin : nitogen ratios of decaying fine root tissues over 13 months in the Tapajos National Forest (Para, Brazil)

Months after trenching

$\begin{array}{lllll}0 & 1 & 5 & 9 & 13\end{array}$

Clay soils

\section{Ash}

Nonpolar extractive

Water soluble carbon

Acid soluble carbon

Tannins

Water soluble glucose

Acid soluble glucose

Lignin

Carbon

Nitrogen

Carbon : nitrogen

Lignin : nitrogen

Sandy soils

Ash

Nonpolar extractive

Water soluble carbon

Acid soluble carbon

Tannins

Water soluble glucose

Acid soluble glucose

Lignin

Carbon

Nitrogen

Carbon : nitrogen

Lignin : nitrogen

\begin{tabular}{|c|c|}
\hline $7.5 \pm 0.3 a$ & $7.7 \pm 0.9 \mathrm{ab}$ \\
\hline $4.8 \pm 0.9 a$ & $4.4 \pm 1.0 \mathrm{a}$ \\
\hline $6.4 \pm 0.4$ & $7.2 \pm 0.2$ \\
\hline $51 \pm 2$ & $52 \pm 2$ \\
\hline $1.2 \pm 0.2$ & $1.0 \pm 0.1$ \\
\hline $1.1 \pm 0.1$ & $1.6 \pm 0.5$ \\
\hline $31 \pm 1$ & $32 \pm 2$ \\
\hline $37 \pm 2$ & $37 \pm 1$ \\
\hline $50.4 \pm 0.6$ & $50.2 \pm 0.9$ \\
\hline $1.5 \pm 0.1$ & $1.4 \pm 0.1$ \\
\hline $35 \pm 1$ & $37 \pm 2$ \\
\hline $26 \pm 2$ & $27 \pm 2$ \\
\hline $6.6 \pm 0.6 a$ & $7.2 \pm 0.9 \mathrm{ab}$ \\
\hline $3.5 \pm 0.7 \mathrm{a}$ & $3.2 \pm 0.9 \mathrm{a}$ \\
\hline $7.8 \pm 1.1$ & $7.8 \pm 0.4$ \\
\hline $48 \pm 2$ & $47 \pm 2$ \\
\hline $1.2 \pm 0.1$ & $1.2 \pm 0.2$ \\
\hline $2.2 \pm 0.9$ & $1.2 \pm 0.1$ \\
\hline $26 \pm 2$ & $25 \pm 2$ \\
\hline $40 \pm 2$ & $42 \pm 2$ \\
\hline $51.1 \pm 0.4$ & $51.1 \pm 0.7$ \\
\hline $1.4 \pm 0.1$ & $1.5 \pm 0.1$ \\
\hline $36 \pm 2$ & $34 \pm 2$ \\
\hline $28 \pm 2$ & $28 \pm 1$ \\
\hline
\end{tabular}

$$
\begin{aligned}
9.5 & \pm 0.6 \mathrm{~b} \\
5.5 & \pm 1.0 \mathrm{ab} \\
7.3 & \pm 1.0 \\
48 & \pm 1 \\
1.0 & \pm 0.2 \\
1.4 & \pm 0.4 \\
26 & \pm 1 \\
39 & \pm 1 \\
47.4 & \pm 0.8 \\
1.6 & \pm 0.1 \\
30 & \pm 1 \\
25 & \pm 2
\end{aligned}
$$

$\begin{aligned} 8.2 & \pm 0.9 \mathrm{~b} \\ 4.9 & \pm 0.5 \mathrm{ab} \\ 7.0 & \pm 0.5 \\ 46 & \pm 2 \\ 0.8 & \pm 0.1 \\ 1.4 & \pm 0.3 \\ 26 & \pm 3 \\ 42 & \pm 2 \\ 51.8 & \pm 0.4 \\ 1.4 & \pm 0.1 \\ 37 & \pm 2 \\ 30 & \pm 1\end{aligned}$

$$
\begin{aligned}
6.3 & \pm 0.9 \mathrm{a} \\
7.6 & \pm 0.3 \mathrm{~b} \\
7.5 & \pm 1.4 \\
52 & \pm 2 \\
1.7 & \pm 0.6 \\
1.9 & \pm 0.9 \\
36 & \pm 2 \\
33 & \pm 3 \\
50.2 & \pm 0.5 \\
1.3 & \pm 0.0 \\
38 & \pm 2 \\
25 & \pm 2
\end{aligned}
$$$$
5.6 \pm 0.4 \mathrm{a}
$$$$
4.5 \pm 0.8 \mathrm{~b}
$$$$
6.7 \pm 0.5
$$$$
44 \pm 1
$$$$
1.0 \pm 0.1
$$$$
1.2 \pm 0.1
$$$$
25 \pm 1
$$$$
45 \pm 2
$$$$
52.7 \pm 0.6
$$$$
1.6 \pm 0.1
$$$$
34 \pm 2
$$$$
30 \pm 3
$$

13

$$
\begin{aligned}
7.3 & \pm 1.3 \mathrm{ab} \\
5.5 & \pm 0.6 \mathrm{ab}^{* * *} \\
7.5 & \pm 1.4 \\
54 & \pm 4^{* * *} \\
1.3 & \pm 0.5 \\
2.1 & \pm 0.8 \\
33 & \pm 4^{* * *} \\
33 & \pm 4^{* * *} \\
50.0 & \pm 1.1^{* * *} \\
1.4 & \pm 0.1 \\
36 & \pm 3 \\
24 & \pm 4^{* *} \\
7.5 & \pm 0.9 \mathrm{ab} \\
3.9 & \pm 0.3 \mathrm{ab} \\
5.9 & \pm 0.2 \\
45 & \pm 3 \\
0.6 & \pm 0.0 \\
1.1 & \pm 0.1 \\
24 & \pm 2 \\
45 & \pm 3 \\
50.3 & \pm 1.2 \\
1.5 & \pm 0.1 \\
33 & \pm 1 \\
30 & \pm 3
\end{aligned}
$$

Lower case letters signify statistically significant differences among dates within a category. Asterisks identify statistically significant differences between soil texture types. Values are means \pm 1 standard error.

$P<0.05,{ }^{* *} P<0.01,{ }^{* * *} P<0.001$.

$(0.41 \pm 0.01 \%)$ than in the controls $(0.36 \pm 0.01 \%)$. Trench plot WFPS in the sandy loam began to diverge from the control about 9 weeks after trenching and remained slightly elevated for most of the rest of the study (Fig. 3). WFPS declined towards the end of the dry season (Julian day 298) in both soil types. There was a weak, positive relationship between soil moisture and percent root mass remaining over time $\left(r^{2}=0.20\right.$, $P=0.05)$ in the clay, and no relation with soil moisture in the sandy loam.

Mineral $\mathrm{N}$ concentrations varied significantly by treatment, texture, and sampling date (Fig. 4). In the control plots, soil ammonium $\left(\mathrm{NH}_{4}^{+}\right)$declined over the first 9 months of the experiment until March 2001; sandy loam soils also experienced the lowest $\mathrm{NH}_{4}^{+}$ concentrations in March 2001. The trench plots followed the same general patterns although concentrations tended to be lower than controls during many of the sampling periods. Soil $\mathrm{NH}_{4}^{+}$concentrations

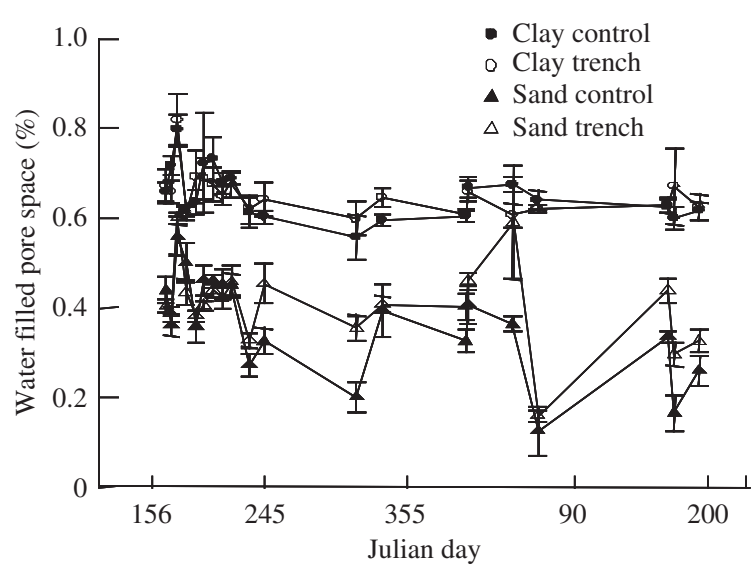

Fig. 3 Percent water-filled pore space $(0-10 \mathrm{~cm}$ depth) in trenched and controls plots on clay and sandy loam soils in the Tapajos National Forest (Para, Brazil). Values are means and standard errors of three samples per plot and five replicate plots per treatment and soil texture type. 
(a)

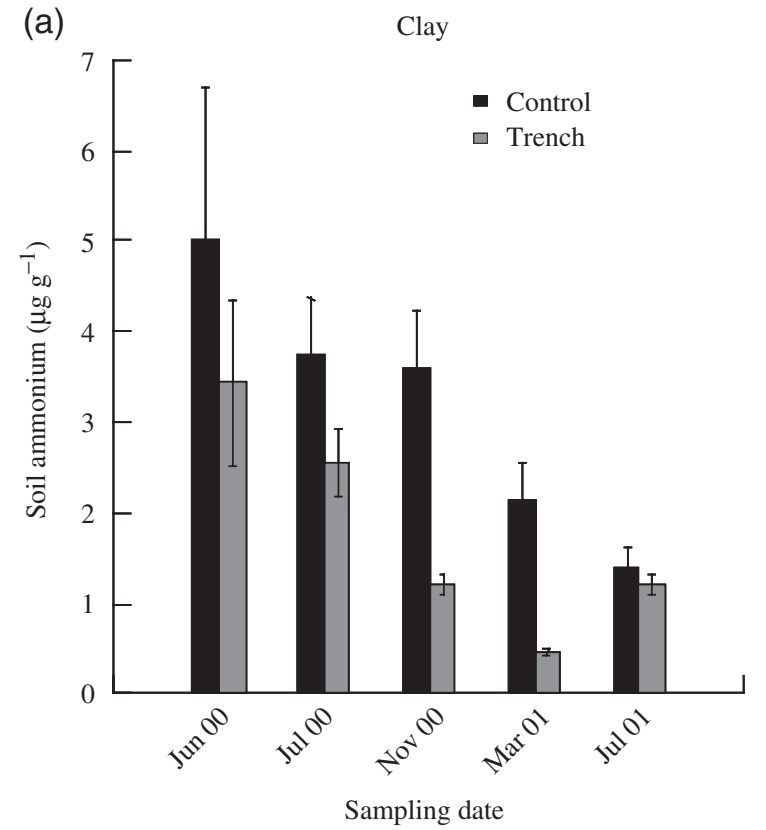

(b)

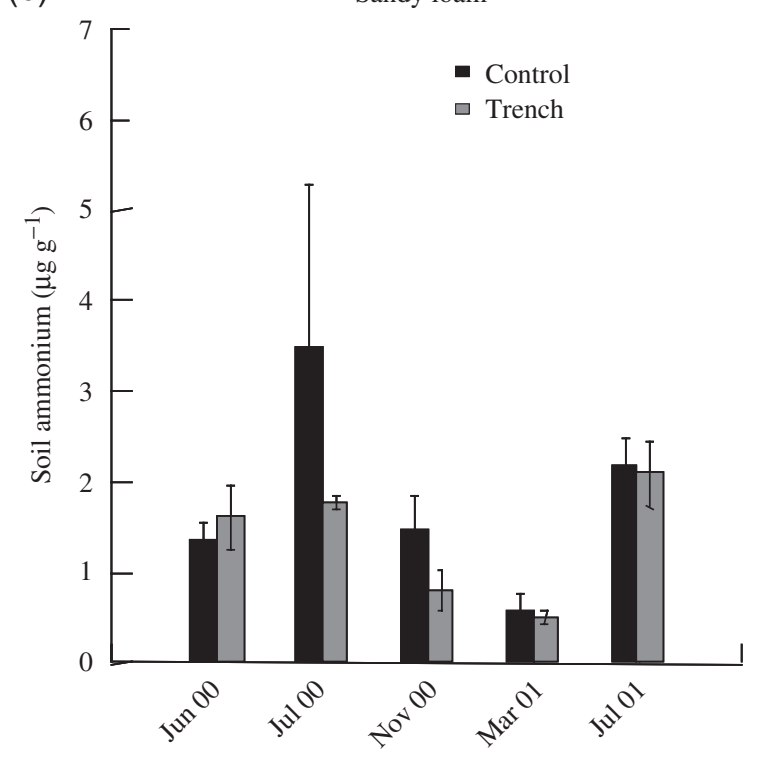

Sampling date

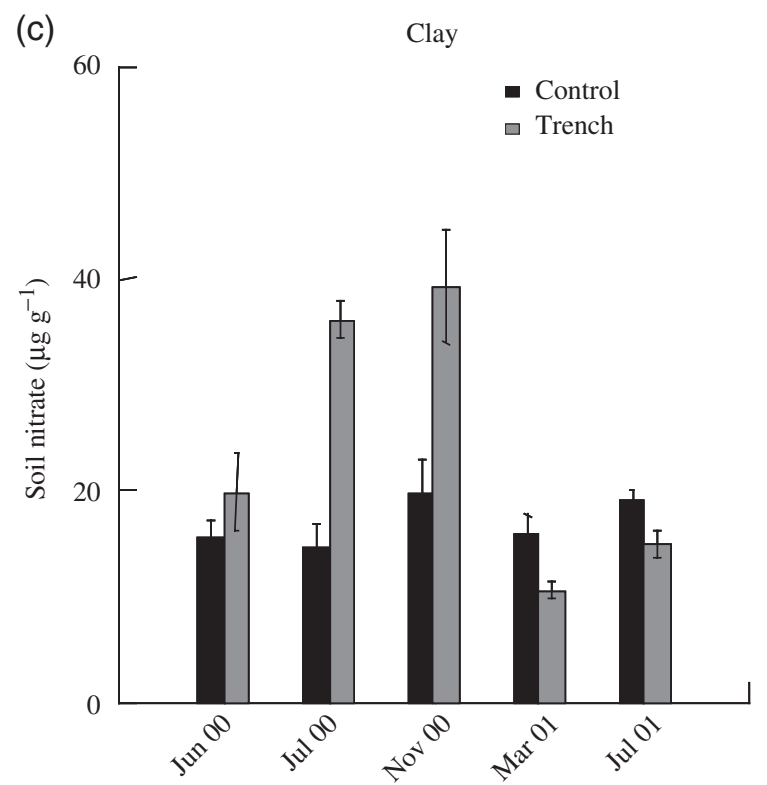

Sampling date

(d)

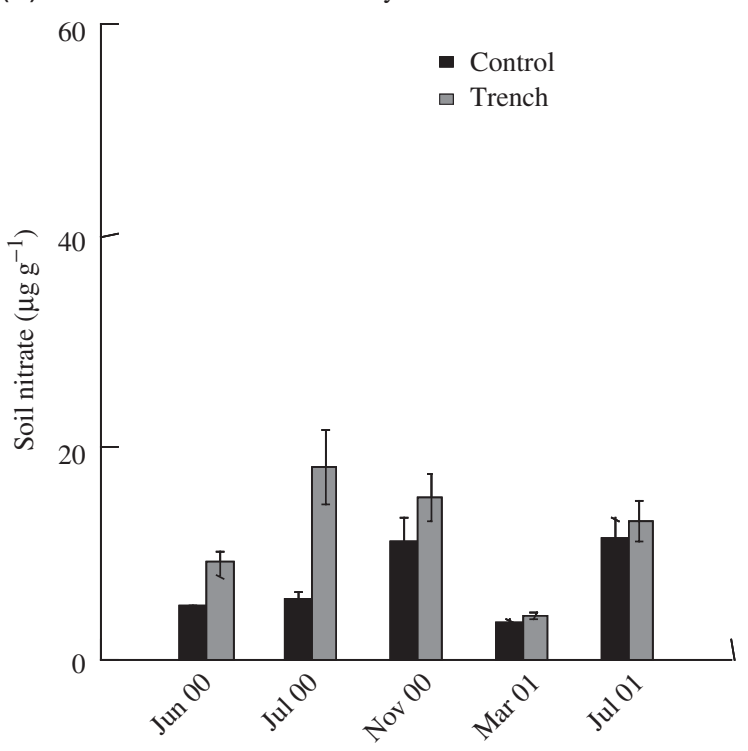

Sampling date

Fig. 4 Soil ammonium and nitrate pools $(0-10 \mathrm{~cm}$ depth) in trenched and control plots on clay (a, c) and sandy loam (b, d) soils in the Tapajos National Forest (Para, Brazil). Values are means and standard errors of three samples per plot and five replicate plots per treatment and soil texture type.

increased significantly in the trench plots and the sandy loam controls at the last sampling date, which was during the second rainy season (Fig. 4a,b). Soil nitrate $\left(\mathrm{NO}_{3}^{-}\right)$concentrations did not vary over time in the clay controls (Fig. 4c). In the sandy loam controls soil $\mathrm{NO}_{3}^{-}$ concentrations were greatest at the start of the rainy season 5 months into the experiment, and again in July 2001 near the end of rainy season (Fig. 4d). Trench plot
$\mathrm{NO}_{3}^{-}$concentrations were significantly higher than controls during the first three sampling periods (up to 5 months following trenching) and then were either lower than or similar to controls (Fig. 4c, d). In clay soils, the percent of root mass remaining over time was positively correlated with soil $\mathrm{NH}_{4}^{+}$pools $\left(r^{2}=0.42, P<0.01\right)$, and weakly positively correlated soil $\mathrm{NO}_{3}^{-}$pools $\left(r^{2}=0.25, P<0.05\right)$. Initial soil $\mathrm{NO}_{3}^{-}$ 
Table 3 Net $\mathrm{N}$ mineralization and nitrification in sand and clay control plots and trenched plots in the Tapajos National Forest (Para, Brazil)

\begin{tabular}{|c|c|c|c|c|}
\hline & & & $\begin{array}{l}\text { Net } N \text { mineralization } \\
\left(\mu \mathrm{g} \mathrm{Ng}_{\mathrm{goil}}{ }^{-1} \mathrm{day}^{-1}\right)\end{array}$ & $\begin{array}{l}\text { Net nitrification } \\
\left(\mu \mathrm{g} \mathrm{Ng} \text { soil }^{-1} \text { day }^{-1}\right)\end{array}$ \\
\hline June 4, 2000 & Clay & Control & $-0.02 \pm 0.28$ & $4.26 \pm 0.30$ \\
\hline June 30, 2000 & Clay & Control & $-0.32 \pm 0.08$ & $2.94 \pm 0.31$ \\
\hline November 3, 2000 & Clay & Control & $0.50 \pm 0.60$ & $3.26 \pm 0.74$ \\
\hline June 4, 2000 & Sand & Control & $1.11 \pm 0.44 \mathrm{a}$ & $0.95 \pm 0.33 a$ \\
\hline June 30, 2000 & Sand & Control & $-0.12 \pm 0.14 \mathrm{~b}$ & $2.45 \pm 0.34 b$ \\
\hline November 3, 2000 & Sand & Control & $0.63 \pm 0.23 b$ & $0.06 \pm 0.42 b$ \\
\hline June 4, 2000 & Clay & Trench & $-0.15 \pm 0.08$ & $1.80 \pm 0.50$ \\
\hline June 30, 2000 & Clay & Trench & $-0.21 \pm 0.08$ & $1.27 \pm 0.38$ \\
\hline November 3, 2000 & Clay & Trench & $-0.01 \pm 0.05$ & $2.59 \pm 0.97$ \\
\hline June 4, 2000 & Sand & Trench & $0.76 \pm 0.14 \mathrm{a}$ & $0.80 \pm 0.17 \mathrm{a}$ \\
\hline June 30, 2000 & Sand & Trench & $-0.10 \pm 0.06 \mathrm{~b}$ & $0.95 \pm 0.58 \mathrm{a}$ \\
\hline November 3, 2000 & Sand & Trench & $0.05 \pm 0.08 a$ & $-1.55 \pm 0.40 \mathrm{~b}$ \\
\hline Variable & & $\mathrm{df}$ & F-ratio & $P$ \\
\hline \multicolumn{5}{|l|}{ Net $N$ mineralization } \\
\hline Date & & 2 & 8.1 & 0.001 \\
\hline Texture & & 1 & 15.1 & 0.000 \\
\hline Date $\times$ texture & & 2 & 4.7 & 0.014 \\
\hline \multicolumn{5}{|l|}{ Net nitrification } \\
\hline Date & & 2 & 3.8 & 0.029 \\
\hline Texture & & 1 & 51.8 & 0.000 \\
\hline Treatment & & 1 & 21.7 & 0.000 \\
\hline Date $\times$ texture & & 2 & 10.7 & 0.000 \\
\hline
\end{tabular}

Values are means and standard errors. Different lower case letters signify statistically significant differences by date. Results from ANOVA are reported below. Only variables and interactions that were statistically significant at the $95 \%$ level or greater are reported.

concentrations (June 4, 2000) explained $61 \%$ of the variability in decay rates for clay and sandy loam soils combined.

Net $\mathrm{N}$ mineralization and nitrification were measured during the first three sampling periods in trenched and control plots (Table 3). Net $\mathrm{N}$ mineralization rates did not vary significantly between controls and trenched plots. Rates were higher in the sandy loam than in the clay, and varied over time in sandy loam, but not in the clay. Rates of net nitrification were lower in the trenched plots than in the controls and were higher in the clay than in the sandy loam soil (Table 3). There was no significant affect of soil moisture or WFPS on rates of $\mathrm{N}$ cycling.

\section{Trace gas dynamics}

Trench plots emitted more than twice the $\mathrm{N}_{2} \mathrm{O}$ as the controls in both clay and sandy loam, and there were significantly greater $\mathrm{N}_{2} \mathrm{O}$ emissions from the clay ( $27 \pm 2$ and $13 \pm 1 \mathrm{ng} \mathrm{N} \mathrm{cm}^{-2} \mathrm{~h}^{-1}$ for trench and control, respectively) than sandy loam $(4.4 \pm 0.5$ and
$1.4 \pm 0.2 \mathrm{ng} \mathrm{N} \mathrm{cm}^{-2} \mathrm{~h}^{-1}$ for trench and control, respectively). $\mathrm{N}_{2} \mathrm{O}$ fluxes from the trench plots remained significantly elevated over controls for most of the study (Fig. 5). In the clays, $\mathrm{N}_{2} \mathrm{O}$ fluxes peaked within weeks after trenching which coincided with a period of high $\mathrm{NO}_{3}^{-}$availability (Fig. 4b). $\mathrm{N}_{2} \mathrm{O}$ fluxes were lowest during the mid to late dry season in both soil types. Mean rates of NO flux were significantly higher in the trenched plots $\left(3.8 \pm 0.9\right.$ and $6.9 \pm 0.8 \mathrm{ng} \mathrm{cm}^{-2} \mathrm{~h}^{-1}$ for clay and sandy loam, respectively) than in the controls $\left(2.9 \pm 0.5\right.$ and $3.8 \pm 0.3 \mathrm{ng} \mathrm{cm}^{-2} \mathrm{~h}^{-1}$ for clay and sandy loam, respectively), and were significantly higher in the sandy loam than in the clay. NO fluxes began increasing in mid-September and peaked in late October in all plots except the clay control (Fig. 6).

Clay and sandy loam control plots, and sandy loam trench plots exhibited net $\mathrm{CH}_{4}$ consumption from the atmosphere at rates ranging from -0.36 ( \pm 0.14$) \mathrm{mg} \mathrm{CH}_{4} \mathrm{~m}^{-2}$ day $^{-1}$ (clay control) to -1.10 ( \pm 0.22$) \mathrm{mg} \mathrm{CH}_{4} \mathrm{~m}^{-2}$ day $^{-1}$ (sandy loam trench). Clay trench plots emitted $\mathrm{CH}_{4}$ at a rate of 3.64 ( \pm 2.70$) \mathrm{mg} \mathrm{CH}_{4} \mathrm{~m}^{-2}$ day $^{-1}$. There were no significant 

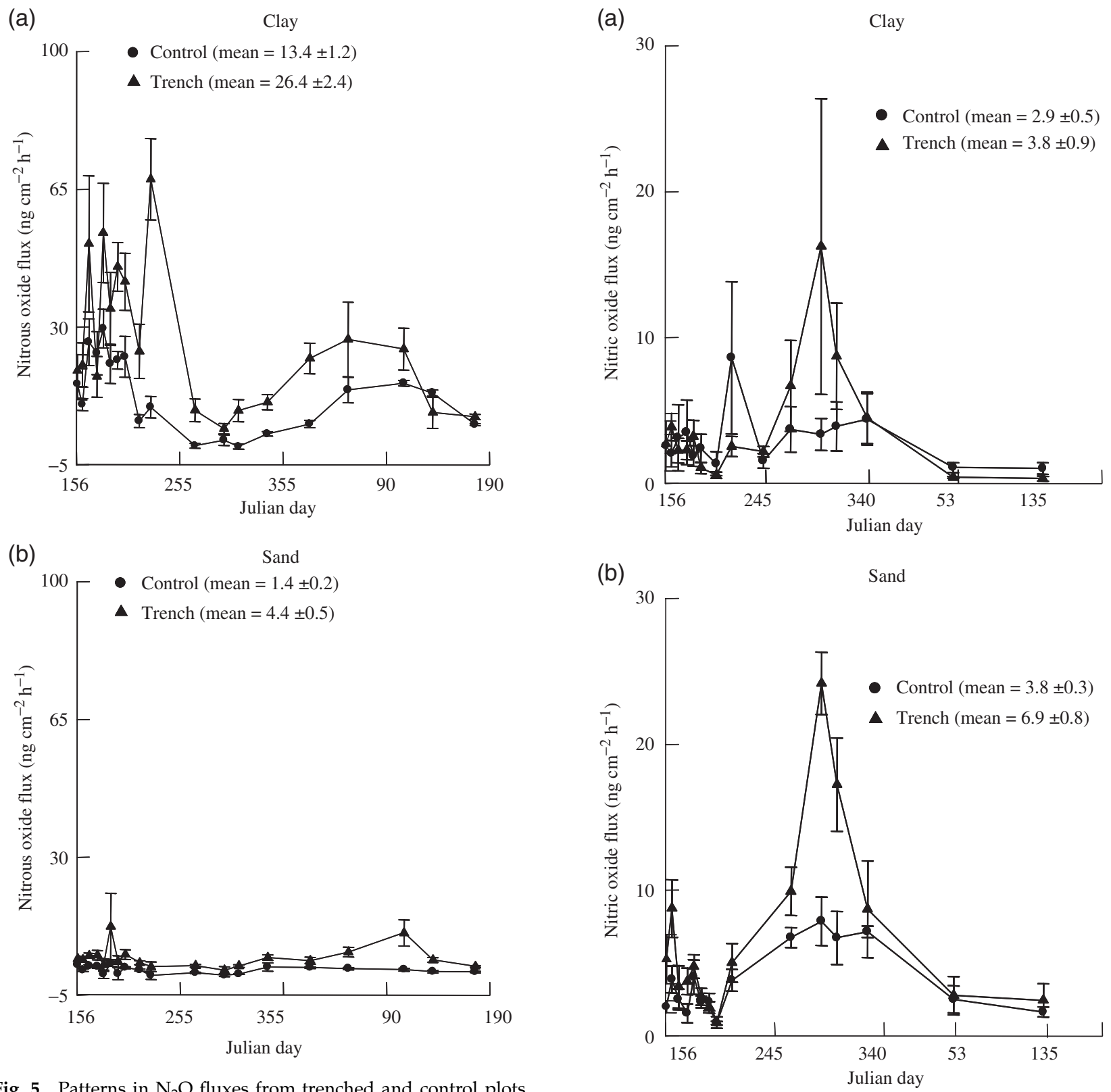

Fig. 5 Patterns in $\mathrm{N}_{2} \mathrm{O}$ fluxes from trenched and control plots on clay (a) and sandy loam (b) soils in the Tapajos National Forest (Para, Brazil). Values are means and standard errors of two flux chambers per plot and five replicate plots per treatment and soil texture type.

effects of treatment, soil texture, or time period on $\mathrm{CH}_{4}$ fluxes in the sandy loamy soils. In clays, there was significantly greater $\mathrm{CH}_{4}$ efflux in the trench plots than the controls because of a large flush of $\mathrm{CH}_{4}$ in the April and May sampling periods (late wet season; data not shown).

Mean soil $\mathrm{CO}_{2}$ fluxes averaged $3.2 \pm 0.1 \mu \mathrm{mol} \mathrm{m}^{-2} \mathrm{~s}^{-1}$ in the clay soils and were significantly lower than in the sandy loam $\left(3.8 \pm 0.1 \mu \mathrm{mol} \mathrm{m}^{-2} \mathrm{~s}^{-1}\right)$. In the clay, trench

Fig. 6 Patterns in NO fluxes from trenched and control plots on clay (a) and sandy loam (b) soils in the Tapajos National Forest (Para, Brazil). Values are means and standard errors of two flux chambers per plot and five replicate plots per treatment and soil texture type.

plots had significantly lower rates of soil respiration $\left(2.8 \pm 0.2 \mu \mathrm{mol} \mathrm{m}^{-2} \mathrm{~s}^{-1}\right)$ than controls. There were no significant differences in mean soil $\mathrm{CO}_{2}$ efflux between treatment and control $\left(3.8 \pm 0.2 \mu \mathrm{mol} \mathrm{m}^{-2} \mathrm{~s}^{-1}\right.$ for both treatments) in the sandy loam. Soil $\mathrm{CO}_{2}$ fluxes showed different temporal patterns with soil texture and with treatments (Fig. 7). Clay control soil experienced two significant dry season declines in soil respiration from 
late June to early August and late September to October. Soil respiration in the trench plots declined after 9 weeks of isolation and remained significantly lower than controls for most of the rest of the study. In the sandy loam, soil respiration in both trench and control plots declined sharply until August, and then increased in the wet season until February 2001.
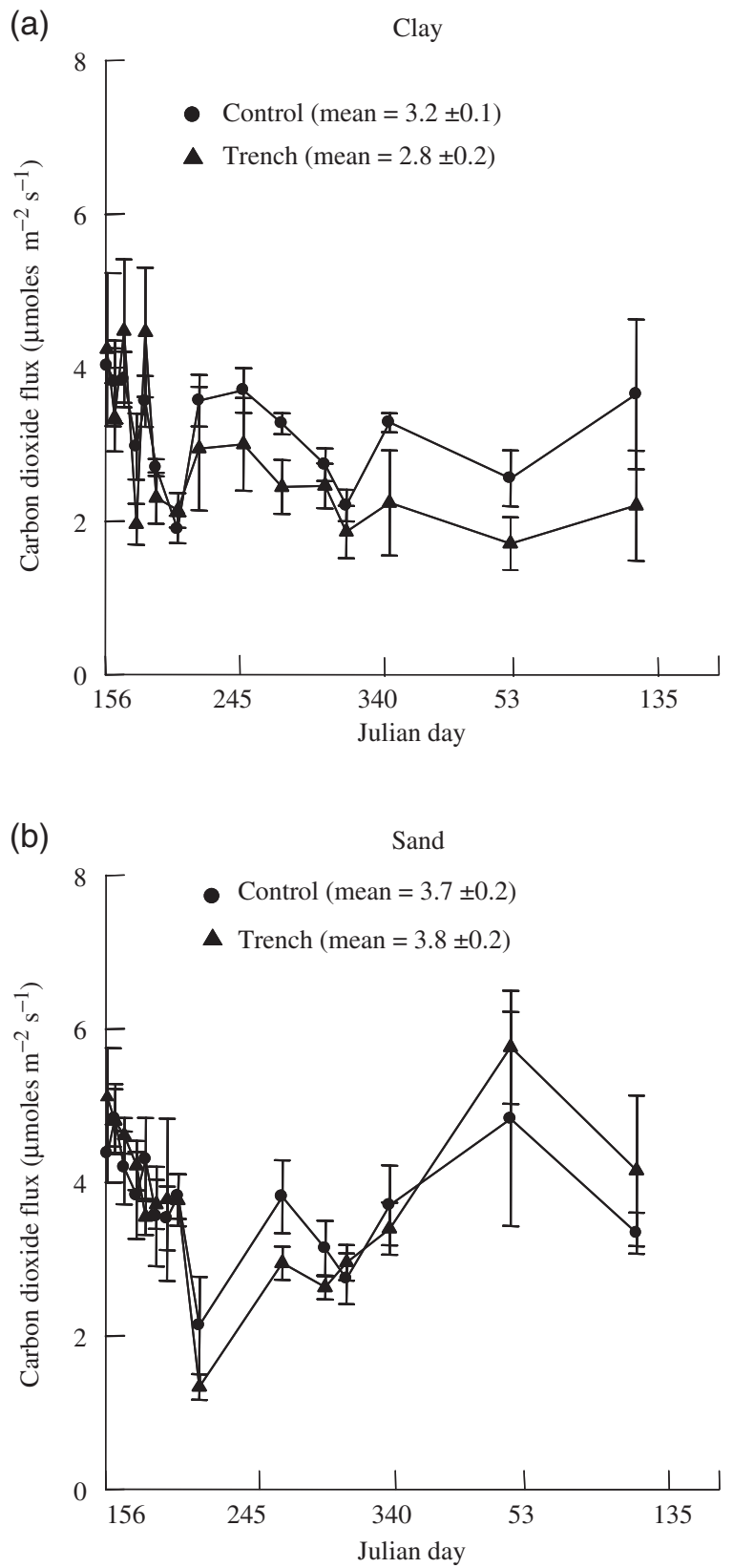

Fig. 7 Patterns in $\mathrm{CO}_{2}$ fluxes from trenched and control plots on clay (a) and sandy loam (b) soils in the Tapajos National Forest (Para, Brazil). Values are means and standard errors of two flux chambers per plot and five replicate plots per treatment and soil texture type.

\section{The contribution of roots to total soil respiration}

The trench plot approach for estimating root respiration assumes that root mortality and decomposition will result in a significant decline in soil $\mathrm{CO}_{2}$ effluxes. In clay soil, $\mathrm{CO}_{2}$ effluxes declined approximately 9 weeks after trenching and remained lower than control plots for the remainder of the study. In the sandy loam, trench plot soil $\mathrm{CO}_{2}$ fluxes were not significantly different from controls during the 13-month study.

Table 4 The contribution of fine roots to total soil respiration in clay (trench and mass balance approaches) and sandy loam (mass balance only) soils of the Tapajos National Forest (Para, Brazil)

\begin{tabular}{|c|c|}
\hline & Trench plot low estimate \\
\hline \multicolumn{2}{|l|}{ Clay soil } \\
\hline Control mean $\mathrm{CO}_{2}$ flux & $1084 \pm 50$ \\
\hline Trench mean $\mathrm{CO}_{2}$ flux & $819 \pm 104$ \\
\hline Control decayed root $\mathrm{C}$ & $115 \pm 11$ \\
\hline Trench decayed root $C$ & $114 \pm 11$ \\
\hline Soil and Litter $\mathrm{CO}_{2}$ flux & $705 \pm 96$ \\
\hline Root respiration & $264 \pm 102$ \\
\hline \multirow[t]{2}{*}{ Root: total soil respiration } & $0.24 \pm 0.09$ \\
\hline & Trench plot high estimate \\
\hline Control mean $\mathrm{CO}_{2}$ flux & $1084 \pm 50$ \\
\hline Trench mean $\mathrm{CO}_{2}$ flux & $819 \pm 104$ \\
\hline Control decayed root $\mathrm{C}$ & 0 \\
\hline Trench decayed root $C$ & $114 \pm 11$ \\
\hline Soil and Litter $\mathrm{CO}_{2}$ flux & $705 \pm 96$ \\
\hline Root respiration & $379 \pm 102$ \\
\hline \multirow[t]{2}{*}{ Root: total soil respiration } & $0.35 \pm 0.09$ \\
\hline & Mass balance estimate \\
\hline Control mean $\mathrm{CO}_{2}$ flux & $1084 \pm 50$ \\
\hline Aboveground litter input & $693 \pm 82$ \\
\hline Belowground litter input & $96 \pm 7$ \\
\hline Root respiration & $295 \pm 51$ \\
\hline \multirow[t]{2}{*}{ Root : total soil respiration } & $0.28 \pm 0.05$ \\
\hline & Mass balance estimate \\
\hline \multicolumn{2}{|l|}{ Sandy loam soil } \\
\hline Control mean $\mathrm{CO}_{2}$ flux & $1363 \pm 209$ \\
\hline Aboveground litter input & $727 \pm 98$ \\
\hline Belowground litter input & $115 \pm 23$ \\
\hline Root respiration & $521 \pm 206$ \\
\hline Root: total soil respiration & $0.35 \pm 0.10$ \\
\hline
\end{tabular}

Values are means of five plots \pm 1 standard error. The low estimate assumes $100 \%$ conversion of decaying roots to $\mathrm{CO}_{2}$. The high estimate assumes no conversion of decaying roots to $\mathrm{CO}_{2}$. Values with the exception of the final ratios are in $\mathrm{gC} \mathrm{m}^{-2} \mathrm{yr}^{-1}$. 
For this reason, we use the trench plot method to estimate the contribution of fine roots to total soil respiration in clay soils only. The root contribution to total soil respiration in clay soils averaged between $24( \pm 0.09) \%$ and $35( \pm 0.09) \%$ of the total soil $\mathrm{CO}_{2}$ efflux (Table 4$)$. For the low estimate, where we assumed $100 \%$ of decaying root $\mathrm{C}$ was converted to $\mathrm{CO}_{2}$, root respiration accounted for approximately $264( \pm 102) \mathrm{g} \mathrm{C} \mathrm{m}^{-2} \mathrm{yr}^{-1}$. When we assumed that none of the decaying root $\mathrm{C}$ was respired as $\mathrm{CO}_{2}$ root respiration amounted to 379 $( \pm 102) \mathrm{gC} \mathrm{m}^{-2} \mathrm{yr}^{-1}$.

We also used a mass balance approach to estimate the root contribution to total soil respiration in both clay and sandy loam soils. In clay soils, root respiration, estimated using a mass balance approach, was strikingly similar to the values acquired using the trench plot technique (Table 4). The ratio of root to soil respiration in clays was intermediate $(0.28 \pm 0.05)$ between the low and high estimates using trenching. Root respiration was somewhat higher in the sandy loam $\left(521 \pm 206 \mathrm{~g} \mathrm{C} \mathrm{m}^{-2} \mathrm{yr}^{-1}\right)$ than in the clay soils, and the ratio of root:soil respiration was $0.35 \pm 0.1$. In general, the variability of litter inputs and $\mathrm{CO}_{2}$ fluxes were higher in the sandy loam than in the clay (Table 4). One potential problem with the mass balance approach was the lack of a root turnover value for the $10-40 \mathrm{~cm}$ depth. When we halved the $0-10 \mathrm{~cm}$ root turnover values and applied this to the $10-40 \mathrm{~cm}$ root pool, it had only a small affect on the proportion of soil respiration attributed to roots (increased the ratio of root to soil respiration to 0.29 and 0.37 for clay and sandy loam, respectively. Data not shown).
We conducted additional analyses to determine how sensitive our trench plot root respiration estimates were to root decay rates, dead root $\mathrm{C}$ losses, and soil $\mathrm{CO}_{2}$ efflux. The proportion of soil respiration attributable to roots was insensitive to changes in root or $\mathrm{CO}_{2}$ parameters when we assumed that all decaying root $\mathrm{C}$ was lost as $\mathrm{CO}_{2}$ (low estimate; Table 5). Root respiration rates, therefore, changed proportionally to changes in soil respiration, but the ratio of root: total soil respiration was unaffected. Our high estimate (no conversion to $\mathrm{CO}_{2}$ during root decay) was more sensitive to changes in parameters. Decreasing the $k$ value alone and in combination with increased root $\mathrm{C}$ respired and/or increased soil $\mathrm{CO}_{2}$ efflux resulted in relatively small changes in the proportion of root respiration from soil ( $<10 \%$ change). The ratio of root to soil respiration was slightly more sensitive to increased dead root $\mathrm{C}$ respired $(+14 \%)$ and decreased soil $\mathrm{CO}_{2}$ efflux $(+11 \%)$. Our results were most sensitive to the combination of increased $\mathrm{C}$ respired from dead root inputs and decreased soil $\mathrm{CO}_{2}$ efflux that resulted in a ratio of root to soil respiration of $0.46(+31 \%)$.

\section{Discussion}

Fine root dynamics in two Amazonian soils

The pools and fluxes of $\mathrm{C}$ and nutrients associated with fine root dynamics can account for a significant proportion of ecosystem-scale biogeochemical cycling. In our study sites, root biomass (fine and coarse)

Table 5 Sensitivity analysis of root decay rate $(k)$ for the $10-40 \mathrm{~cm}$ depth, $\mathrm{C}$ respiration attributed to dead root inputs, and soil $\mathrm{CO}_{2}$ efflux for calculating the root contribution to soil respiration

\begin{tabular}{|c|c|c|c|c|c|c|}
\hline & \multicolumn{2}{|c|}{$\begin{array}{l}\text { Root } \\
\text { respiration }\end{array}$} & \multicolumn{2}{|c|}{$\begin{array}{l}\text { Root: soil } \\
\text { respiration }\end{array}$} & \multicolumn{2}{|c|}{$\begin{array}{l}\text { Root: soil } \\
\text { percent } \\
\text { change }\end{array}$} \\
\hline & Low & High & Low & High & Low & High \\
\hline Measured values & 264 & 380 & 0.24 & 0.35 & - & - \\
\hline Decreased $k$ value $(\times 50 \%)$ & 264 & 362 & 0.24 & 0.33 & 0 & -6 \\
\hline Increased $C$ respired from dead root input $(\times 50 \%)$ & 263 & 437 & 0.24 & 0.40 & 0 & +14 \\
\hline Increased soil $\mathrm{CO}_{2}$ flux $(\times 25 \%)$ & 330 & 446 & 0.24 & 0.33 & 0 & -6 \\
\hline Decreased soil $\mathrm{CO}_{2}$ flux $(\times 25 \%)$ & 197 & 313 & 0.24 & 0.39 & 0 & +11 \\
\hline Decreased $k$ value and increased $C$ respired from dead root input & 263 & 411 & 0.24 & 0.38 & 0 & +9 \\
\hline Decreased $k$ value and increased soil $\mathrm{CO}_{2}$ flux & 330 & 428 & 0.24 & 0.32 & 0 & -9 \\
\hline Decreased $k$ value and decreased soil $\mathrm{CO}_{2}$ flux & 197 & 296 & 0.24 & 0.36 & 0 & +3 \\
\hline Increased $\mathrm{C}$ respired from dead root input and increased soil $\mathrm{CO}_{2}$ flux & 329 & 503 & 0.24 & 0.37 & 0 & +6 \\
\hline Increased $\mathrm{C}$ respired from dead root input and decreased soil $\mathrm{CO}_{2}$ flux & 197 & 371 & 0.24 & 0.46 & 0 & +31 \\
\hline Decreased $k$ value, increased $\mathrm{C}$ respired from dead root input, and increased soil $\mathrm{CO}_{2}$ flux & 329 & 477 & 0.24 & 0.35 & 0 & - \\
\hline Decreased $k$ value, increased $\mathrm{C}$ respired from dead root input, and decreased soil $\mathrm{CO}_{2}$ flux & 197 & 345 & 0.24 & 0.42 & 0 & +20 \\
\hline
\end{tabular}

See text for the equations used to estimate root respiration. Root respiration is in $\mathrm{gC}^{-2} \mathrm{yr}^{-2}$. 
accounts for approximately one-quarter to one-third of the belowground $\mathrm{C}$ pool in the top meter of mineral soil, and approximately $50 \%$ of the C in the top $10 \mathrm{~cm}$ of mineral soil (Silver et al., 2000). Although fine roots account for less biomass than coarse roots, they grow and turn over faster. Here, the $\mathrm{C}$ allocation to fine roots was approximately $1 \mathrm{MgCha}^{-1} \mathrm{yr}^{-1}$ over the 2-year study, of which approximately 60\% turned over annually. Our results highlight the likelihood for variable lifespans of fine roots some of which may persist for multiple years (Gaudinski et al., 2001). We can use our estimates of fine root turnover and decay in year 2 of our study to determine if this ecosystem is in a relative steady-state condition with regard to fine root production and decomposition. Root turnover deposited approximately $157( \pm 22)$ and 149 $( \pm 54) \mathrm{g} \mathrm{m}^{-2} \mathrm{yr}^{-1}$ of root tissue to the soil for clay and sandy loam, respectively, and root loss via decay was $172( \pm 16)$ and $162( \pm 40) \mathrm{g} \mathrm{m}^{-2} \mathrm{yr}^{-1}$ for the two soil types. This suggests that there was a relative balance between senescence and decay for the second year of the study. It is important to note that while this pattern suggests a steady-state condition for root dynamics over a 1-year period, other recent studies from this forest have highlighted the significant interannual variability of $C$ fluxes at an ecosystem scale (Rice et al., 2004). Rates of fine root productivity and turnover measured in this study are comparable with forests growing on similar soils and under similar climate regimes (Vogt et al., 1996; Gill \& Jackson, 2000).

There was more fine root biomass in sandy loam soils than in clay, although rates of fine root productivity and turnover did not differ significantly between the two textural types. Root decay rates differed with soil texture, with slower rates in the sandy loam. The combination of similar root production and slower root decay in the sandy loam relative to clay led to greater standing stocks of dead roots in sandy loam soils. There are several factors that could contribute to slower rates of root decay in sandy loam than in nearby clay soils including water limitation to decomposer organisms during part of the year, poor litter quality, and/or low soil nutrient availability. We found no direct correlation between water availability and root decay in sandy loam soils, and a negative relationship with decay in clay. There was no significant correlation with indices of root chemical quality and root decay in either sandy loam or clay. Rates of leaf litter decay are often best predicted by litter quality (Aerts, 1997), but root decay may be more sensitive to climate, and soil chemical and physical properties (Ostertag, 2001; Silver \& Miya, 2001). In this study, changes in the mineral $\mathrm{N}$ availability over time and the initial soil $\mathrm{NO}_{3}^{-}$pool were positively correlated with fine root decay.
Although it is possible that $\mathrm{N}$ limits root decay, it is also possible that the positive relationships between root decay and mineral $\mathrm{N}$ concentrations could be a result of increasing substrate availability for $\mathrm{N}$ mineralization and nitrification with decay, and decreased plant uptake of mineral $\mathrm{N}$ because of root mortality. Highly weathered tropical forests are generally considered to be more limited by P than by N (Vitousek \& Sanford, 1986). In these soils, fine roots in sandy loam had twice the tissue $\mathrm{P}$ content $\left(1.6 \pm 0.1 \mathrm{~kg} \mathrm{ha}^{-1}\right)$ as roots in clay $\left(0.8 \pm 0.1 \mathrm{~kg} \mathrm{ha}^{-1}\right)$, and sandy loam generally had about two times more extractable soil $\mathrm{P}$ (Silver et al., 2000) suggesting that tissue $\mathrm{P}$ or soil $\mathrm{P}$ availability cannot explain the patterns observed.

\section{The effects of root decomposition on trace gas fluxes}

Root death and decomposition had a large and significant impact on trace gas fluxes. High $\mathrm{N}_{2} \mathrm{O}$ fluxes occurred from the trench plots over the 1-year period. Average $\mathrm{N}_{2} \mathrm{O}$ emissions in the clay trench plots were double that of the controls and were three times higher in the sandy loam trench plots relative to controls. We speculate that this increased $\mathrm{N}_{2} \mathrm{O}$ was derived both from nitrification and denitrification. Rates of net mineralization and nitrification did not vary consistently with $\mathrm{N}_{2} \mathrm{O}$ fluxes. However, the highest fluxes were associated with periods of high $\mathrm{NO}_{3}^{-}$availability. High nitrate availability favors $\mathrm{N}_{2} \mathrm{O}$ release as opposed to complete reduction to $\mathrm{N}_{2}$ under denitrification (Nõmmik, 1956). Oxygen demand by decaying roots probably decreased soil redox potential in a significant proportion of soil microsites in the clay. Periodic reducing events have been measured in other humid tropical forest soils (Silver et al., 1999, 2001) and have been shown to stimulate both $\mathrm{NO}_{3}^{-}$and $\mathrm{C}$ reduction. Here, we observed net $\mathrm{CH}_{4}$ production in the clay trench plots, presumably also from anaerobic microsites. In the sandy loam, nitrification was probably the dominant source of $\mathrm{N}_{2} \mathrm{O}$ because soils are well drained and aerated. Under these conditions, weak or shortterm reducing events can stimulate the release of $\mathrm{N}_{2} \mathrm{O}$ during nitrification from normally well-aerated soils (Bollmann \& Conrad, 1998).

Our results suggest that root mortality and decomposition are important mechanisms contributing to increased $\mathrm{N}_{2} \mathrm{O}$ emissions following disturbance in tropical forests. Previous research had shown that short-term root mortality in tropical forest soils can lead to increases of soil $\mathrm{N}_{2} \mathrm{O}$ emissions (Matson et al., 1990; Keller et al., 2000; Varner et al., 2003). The yearlong increase in $\mathrm{N}_{2} \mathrm{O}$ fluxes that we observed highlight the crucial roles of roots and rhizosphere organisms in the regulation of $\mathrm{N}_{2} \mathrm{O}$ emissions. Root mortality and 
decay can stimulate $\mathrm{N}$ mineralization and nitrification, while removing root uptake of inorganic N (Silver \& Vogt, 1993). These factors are likely to lead to increased $\mathrm{N}$ availability for nitrifiers and denitrifiers.

Unlike the pattern for $\mathrm{N}_{2} \mathrm{O}$, Varner et al. (2003) found no short-term effect of root mortality on $\mathrm{NO}, \mathrm{CO}_{2}$, or $\mathrm{CH}_{4}$ fluxes. In this study, we found that mean $\mathrm{NO}$ fluxes increased as roots decayed, particularly during the early rains of the wet season. Wet-up of dry soil often leads to increased NO emissions (Anderson \& Poth, 1989; Davidson et al., 1991; Davidson, 1992; Gasche \& Papen, 1999), and root death and decay enhanced this affect. Rates of NO efflux were higher in the sandy loam, and were higher than average $\mathrm{N}_{2} \mathrm{O}$ fluxes in that soil. In the clay, NO fluxes were much lower than $\mathrm{N}_{2} \mathrm{O}$ fluxes. Greater diffusivity in the sandy loam compared with the clay probably increases the likelihood that biologically active NO can escape from the soil (Bakwin et al., 1990; Davidson, 1993; Bollmann \& Conrad, 1998). The total amount of $\mathrm{N}$ emitted from the soil as NO over the course of the study was similar to rates reported for other moist tropical forests (Davidson \& Kingerlee, 1997).

Soil respiration at our sites $\left(1.1\right.$ and $1.4 \mathrm{~kg} \mathrm{C} \mathrm{m}^{-2} \mathrm{yr}^{-1}$ for clay and sandy loam, respectively) was similar to the average rate of $1.2 \mathrm{~kg} \mathrm{C} \mathrm{m}^{-2} \mathrm{yr}^{-1}$ reported for other moist tropical forests (Raich \& Schlesinger, 1992; Davidson et al., 2002). The sandy loam had greater soil respiration rates than the clay, which is probably indicative of the greater belowground necromass, and hence substrate for heterotrophs in these well-drained soils.

\section{The root contribution to soil respiration}

Soil respiration decreased by an average of $13 \%$ over the study period in the clay trench plots. This yielded an approximate rate of $\mathrm{C}$ loss via root respiration of 2.6$3.7 \mathrm{MgCha}^{-1} \mathrm{yr}^{-1}$. Our estimates of the root contribution to soil respiration in clay soil range from $24 \%$ to $35 \%$. These values are both low when compared with other estimates of root respiration in tropical forest soils and forest soils in general, which average 50-60\% (Hanson et al., 2000). In the Amazon, Chambers et al. (2004) estimated that root respiration accounted for $45 \%$ of soil respiration for a forest site near Manaus. The proportion of soil respiration attributed to roots is low regardless of the assumptions regarding decay efficiency by microbes. Our low estimate assumes 100\% conversion of decayed roots to $\mathrm{CO}_{2}$ and our high estimate assumes no $\mathrm{CO}_{2}$ loss from root decay, both of which are unrealistic and extreme. It is important to note that our estimates of $C$ lost via root respiration are not particularly low, but that our estimate of the bulk soil heterotrophic respiration associated with soil organic matter decay is higher than those reported elsewhere. The high net primary productivity (Clark et al., 2001), large microbial biomass (Rillig et al., 2001), and rapid rates of $\mathrm{C}$ turnover in humid tropical forest soils (Trumbore et al., 1995; Telles et al., 2003) are likely to support high rates of bulk soil heterotrophic respiration.

Estimating the root contribution to soil respiration is not without problems and values are likely to reflect the method used. Our trench plot approach is more comprehensive than most trenching experiments in that we directly accounted for root decay and removed all germination and sprouts. Regardless, there are several potential sources of error in our estimates. First, we measured roots only in the top $10 \mathrm{~cm}$ of soil. Roots in this forest extend much deeper, although the vast majority of biomass is concentrated within 10 to $20 \mathrm{~cm}$ of the surface (Silver et al., 2000). To partially address this issue, we accounted for biomass from the 10 to $40 \mathrm{~cm}$ depth in our equation, using data from roots sampled outside of the trench plots. We applied the decomposition constant from the 0 to $10 \mathrm{~cm}$ depth, which is likely to over estimate the rate of decay and bias our estimate in favor of root respiration. Decreasing the rate of decay for deeper roots had only a small impact on the ratio of root to soil respiration, presumably because of the low root biomass at depth. When we increased our value for root $C$ respired during decay by $50 \%$, we increased our maximum estimate of root respiration by only $15 \%$.

We may also have under- or overestimated soil respiration. Davidson et al. (2000) reported much greater rates of soil respiration $\left(2.0 \mathrm{~kg} \mathrm{C} \mathrm{m}^{-2} \mathrm{yr}^{-1}\right)$ for an Amazonian forest receiving less rainfall $\left(1800 \mathrm{~mm} \mathrm{yr}^{-1}\right)$ than our site, while Chambers et al. (2004) reported $1.2 \mathrm{kgC} \mathrm{m}^{-2} \mathrm{yr}^{-1}$ for a wetter forest $\left(2965 \mathrm{~mm} \mathrm{yr}^{-1}\right)$. Increasing our estimate for soil $\mathrm{CO}_{2}$ efflux increased our high estimate of root respiration by $17 \%$ but decreased the ratio of root to soil respiration by $6 \%$. Decreasing our estimated values for soil respiration had a larger effect, particularly when considered in conjunction with increased root $\mathrm{C}$ loss. With this scenario, the ratio of root to soil respiration was 0.46 , similar to the rate reported for other tropical forests. It is important to note that the assumption used in this estimate (no $\mathrm{CO}_{2}$ loss from decaying roots) is unrealistic, and that the real root respiration rate, even if we underestimated root $\mathrm{C}$ loss and overestimated soil respiration, is likely to be lower.

We were unable to estimate root respiration in sandy loam soils using the trench plot approach because total soil respiration in the trench plots was indistinguishable from the controls over the 13-month study. The 
trenching approach assumes that root mortality will decrease soil respiration rates after root decay is accounted for, and that the resulting soil $\mathrm{CO}_{2}$ efflux is fueled exclusively by heterotrophic respiration of soil organic matter and older necromass. We expect that a combination of factors is responsible for our inability to detect root respiration in the sandy loam using trench plots. First, high initial root biomass coupled with slow root decay rates relative to clay soils led to more gradual loss of the roots deposited via trenching. Second, trenching could have altered soil conditions such as moisture or nutrient availability and stimulated decay of recalcitrant soil and root $\mathrm{C}$, raising soil $\mathrm{CO}_{2}$ effluxes and offsetting the loss of live root respiration. These issues could also have affected trench plot root respiration estimates in the clay soils, although the associated errors are proportional to the pools and fluxes and are thus likely to be much smaller in the clay soils. Finally, root processes were generally more variable in space and time in the sandy loam soils contributing to the lack of significant deviation from controls.

The mass balance approach is an indirect method of estimating root respiration. The strengths of this approach are that some of the parameters used (aboveground litter inputs, soil $\mathrm{CO}_{2}$ fluxes) are generally easier to measure. The most significant problem with this method is the steady-state assumption, which may or may not be met over the time scale of 1 year in an evergreen tropical forest (Saleska et al., 2003), and is difficult to assess. Regardless, the ratio of root to soil respiration using the mass balance approach was very similar to the trench plot values for clay soils, falling between the high and low estimates reported. Rates of root respiration averaged approximately $5 \pm 2 \mathrm{MgC} \mathrm{ha}^{-1} \mathrm{yr}^{-1}$ in the sandy loams using the mass balance approach, with a ratio of root to soil respiration of $0.35 \pm 0.1$. These rates are lower than literature values, but can be explained by the high dead root biomass and soil $\mathrm{C}$ pools in the sandy loam soils. The ratio of root to soil respiration using the mass balance approach reported here are lower than those from other Amazonian forests (Trumbore et al., 2005), due in part to the high litterfall rates measured here. Fine litterfall productivity for this study (leaves, flowers, fruits, and twigs $<1 \mathrm{~cm}$ diameter: $6.9-7.3 \mathrm{MgC} \mathrm{ha}^{-1} \mathrm{yr}^{-1}$ ) was greater than litterfall rates in some other tropical forests (Clark et al., 2001), including those reported for another site within the TNF (2.9-4.8 $\mathrm{MgC} \mathrm{ha}^{-1} \mathrm{yr}^{-1}$ in Nepstad et al., 2002) and for a Amazonian forest near Manaus (4.0 $\mathrm{MgC} \mathrm{ha}^{-1} \mathrm{yr}^{-1}$ in Chambers et al., 2004). However, another study in the Tapajos Forest measured $6 \mathrm{MgCha}^{-1} \mathrm{yr}^{-1}$ in fine litterfall (including twigs up to $2 \mathrm{~cm}$ diameter; Rice et al., 2004). Hence, aboveground litterfall appears to vary both spatially and temporally within this region. For our mass balance approach we include the input of fine root litter, not just aboveground litterfall. Most other mass balance estimates of root respiration do not consider root litter, and thus may overestimate the root contribution to soil respiration.

\section{Conclusions}

Our results show that fine root production, turnover, and decomposition constitute large fluxes of $\mathrm{C}$ and $\mathrm{N}$ in lowland Amazonian forest ecosystems, are sensitive to soil texture, and vary at seasonal and annual time scales. Live root respiration contributed to the large fluxes of $\mathrm{C}$ from surface soils. Although root respiration rates are not low compared with other sites (Hanson et al., 2000), they accounted for only $24-35 \%$ of the total soil respiration flux in the clay and sandy loam soils. These low values illustrate the importance of nonrhizosphere heterotrophic respiration in tropical forests soils that are characterized by high rates of $C$ throughput. Our results also demonstrate the importance of root death and decay as important processes regulating the soil-atmosphere exchange of trace gases, in particular $\mathrm{N}_{2} \mathrm{O}$ and NO. The role of roots in $\mathrm{C}$ and $\mathrm{N}$ cycling are significant not only for our understanding of the contribution of fine root dynamics to ecosystem biogeochemical cycling, but also for helping us predict the effects of deforestation and land use change in the tropics.

\section{Acknowledgements}

We appreciate the field assistance provided by Francisco Aves, Cleuton Batista Pereira, Kadson Oliveira da Silva, and Wanderley de Oliveira Pereira, and stimulating conversations on this topic with M. S. Torn. This study was part of the Brazil-led Large Biosphere-Atmosphere Experiment in Amazonia (LBA) and was funded by NASA's Office of Earth Science (TG-07\#23885). Additional support was provided by grants from the A. W. Mellon Foundation to W. Silver, NSF-LTER\#BSR-8811902 as a component of cross-site activities, and was done under the California Agricultural Experiment Station projects \#6363-MS (W. L. S.).

\section{References}

Aerts R (1997) Climate, leaf litter chemistry and leaf litter decomposition in terrestrial ecosystems: a triangular relationship. Oikos, 79, 439-449.

Anderson IC, Poth MA (1989) Semiannual losses of nitrogen as $\mathrm{NO}$ and $\mathrm{N}_{2} \mathrm{O}$ from unburned and burned chaparral. Global Biogeochemical Cycles, 3, 121-135.

Bakwin P, Wofsy SC, Fan SM et al. (1990) Emission of nitric oxide (NO) from tropical forest soils and exchange of $\mathrm{NO}$ between 
the forest canopy and atmospheric boundary layers. Journal of Geophysical Research, 95, 16755-16764.

Bollmann A, Conrad R (1998) Influence of $\mathrm{O}_{2}$ availability on $\mathrm{NO}$ and $\mathrm{N}_{2} \mathrm{O}$ release by nitrification and denitrification in soils. Global Change Biology, 4, 387-396.

Bouwman AF, Fung I, Matthews E et al. (1993) Global analysis of the potential for $\mathrm{N}_{2} \mathrm{O}$ production in natural soils. Global Biogeochemical Cycles, 7, 557-597.

Chambers JQ, Tribuzy ES, Toledo LC et al. (2004) Respiration from a tropical forest ecosystem: partitioning of sources and low carbon use efficiency. Ecological Applications, 14, s72-s88.

Chameides WL, Fehsenfeld F, Rodgers MO (1992) Ozone precursor relationships in the ambient atmosphere. Journal of Geophysical Research, 97, 6037-6055.

Chen H, Harmon ME, Sexton J et al. (2002) Fine-root decomposition and $\mathrm{N}$ dynamics in coniferous forests of the Pacific Northwest, U.S.A. Canadian Journal of Forest Research, 32, 320-331.

Clark DA, Brown S, Kicklighter D et al. (2001) Evaluation and synthesis of existing field NPP data: tropical forests. Ecological Applications, 11, 371-384.

Cuevas E, Medina E (1986) Nutrient dynamics within Amazonian forest ecosystems 1 . Nutrient flux in fine litter fall and efficiency of nutrient utilization. Oecologia, 68, 466-472.

Cuevas E, Medina E (1988) Nutrient dynamics within Amazonian forests: 2 . Fine root growth, nutrient availability and leaf litter decomposition. Oecologia, 76, 222-235.

Davidson EA (1992) Sources of nitric oxide and nitrous oxide following wetting of dry soil. Soil Science Society of America Journal, 56, 95-102.

Davidson EA (1993) Soil water content and the ratio of nitrous oxide to nitric oxide emitted from soil. In: Biogeochemistry of Global Chang (ed. Oremland RS), pp. 369-386. Chapman \& Hall, New York.

Davidson EA, Kingerlee K (1997) A global inventory of nitric oxide emissions from soils. Nutrient Cycling in Agroecosystems, 48, 37-50.

Davidson EA, Savage K, Bolstad PD et al. (2002) Belowground carbon allocation in forests estimated from litterfall and IRGAbased soil respiration measurements. Agricultural and Forest Meteorology, 113, 39-51.

Davidson EA, Verchot LV, Cattanio HJ et al. (2000) Effects of soil water content on soil respiration in forests and cattle pastures of eastern Amazonia. Biogeochemistry, 48, 53-69.

Davidson EA, Vitousek PM, Matson PA et al. (1991) Soil emissions of nitric oxide in a seasonally dry tropical forest of Mexico. Journal of Geophysical Research, 96, 15439-15445.

Gasche R, Papen H (1999) A 3-year continuous record of nitrogen trace gas fluxes from untreated and limited soil of a $\mathrm{N}$-saturated spruce and beech forest ecosystem in Germany 2. $\mathrm{NO}$ and $\mathrm{NO}_{2}$ fluxes. Journal of Geophysical Research, 104, 18505-18520.

Gaudinski JB, Trumbore SE, Davidson EA et al. (2001) The age of fine-root carbon in three forests of the eastern United States measured by radiocarbon. Oecologia, 129, 420-429.

Gill R, Jackson RB (2000) Global patterns of root turnover for terrestrial ecosystems. New Phytologist, 147, 13-31.

Hanson PJ, Edwards NT, Garten CT et al. (2000) Separating root and soil microbial contributions to soil respiration: a review of methods and observations. Biogeochemistry, 48, 115-146.
Hart SC, Stark JM, Davidson EA et al. (1994) Nitrogen mineralization, immobilization, and nitrification. In: Methods of Soil Analysis, Part 2. Microbiological and Biochemical Properties (ed.Weaver RW pp. 985-1018. Soil Science Society of America, Madison.

Högberg P, Nordgren A, Ågren GI (2002) Carbon allocation between tree root growth and root respiration in boreal pine forest. Oecologia, 132, 579-581.

Jackson RB, Manwaring JH, Caldwell MM (1990) Rapid physiological adjustment of roots to localized soil enrichment. Nature, 344, 58-60.

Keller M, Jacob DJ, Wofsy SC et al. (1991) Effects of tropical deforestation on global and regional atmospheric chemistry. Climatic Change, 19, 139-158.

Keller M, Mitre ME, Stallard RF (1990) Consumption of atmospheric methane in tropical soils: effects of agricultural development. Global Biogeochemical Cycles, 4, 21-27.

Keller M, Palace M, Hurtt GE (2001) Biomass in the Tapajos National Forest, Brazil: examination of sampling and allometric uncertainties. Forest Ecology and Management, 154, 371-382.

Keller M, Veldkamp E, Weitz AM et al. (1993) Effect of pasture age on soil trace-gas emissions from a deforested area of Costa Rica. Nature, 365, 244-246.

Keller M, Weitz AM, Bryan B et al. (2000) Soil-atmosphere nitrogen oxide fluxes: effects of root disturbance. Journal of Geophysical Research, 105, 17693-17698.

Matson PA, Vitousek PM, Livingston GP et al. (1990) Sources of variation in nitrous oxide flux from Amazonian ecosystems. Journal of Geophysical Research, 95, 16789-16798.

McGroddy ME (2002) The fate of phosphorus in a seasonal, lowland Amazonian ecosystem: biological cycling vs. geochemical sequestration. PhD Thesis, University of California, Berkeley, CA, USA, 157 pp.

McGroddy ME, Silver WL, Cosme de Oliveira Jr. R (2004) The effect of phosphorus availability on decomposition dynamics in a seasonal lowland Amazonian forest. Ecosystems, 7, 172-179.

Nepstad D, Moutinho P, Dias-Filho MB et al. (2002) The effect of partial throughfall exclusion on canopy processes and biogeochemistry of an Amazon forest. Journal of Geophysical Research, 107, 1-18.

Nõmmik H (1956) Investigations on denitrification. Acta Agriculturae Scandinavica, 6, 195-228.

Ostertag R (2001) Effects of phosphorus and nitrogen availability in fine root dynamics in Hawaiian montane forests. Ecology, 82, 485-499.

Parrotta JA, Francis JK, Rolo de Almeida R (1995) Trees of the Tapajos: A photographic Field Guide. United States Department of Agriculture Forest Service International Institute of Tropical Forestry, Rio Piedras, Puerto Rico.

Prather MJ, Derwent R, Ehhalt D et al. (1995) Other trace gases and atmospheric chemistry. In: Climate Change 1994 (eds Houghton JT et al.), pp. 73-126. Cambridge University Press, Cambridge.

Publicover DA, Vogt KA (1993) A comparison of methods for estimating forest fine root production with respect to sources of error. Canadian Journal of Forest Research, 23, 1179-1186.

Raich JW, Schlesinger WH (1992) The global carbon dioxide flux in soil respiration and relationship to vegetation and climate. Tellus, 44B, 81-99. 
Rice AH, Pyle EH, Saleska SR et al. (2004) Carbon balance and vegetation dynamics in an old growth Amazonian forest. Ecological Applications, 14, s55-s71.

Rillig M, Wright SF, Nichols KA et al. (2001) Large contribution of arbuscular mycorrhizal fungi to soil carbon pools in tropical forest soils. Plant and Soil, 233, 167-177.

Rummel U, Ammann C, Gut A et al. (2002) Eddy covariance measurements of nitric oxide flux within an Amazonian rain forest. Journal of Geophysical Research, 107, 8050-8058.

Ryan MG, Melillo JM, Ricca A (1989) A comparison of methods for determining proximate carbon fractions of forest litter Canadian Journal of Forest Research, 20, 166-171.

Saleska SR, Miller SD, Matross DM et al. (2003) Carbon in Amazon forests: unexpected seasonal fluxes and disturbanceinduced losses. Science, 302, 1554-1557.

Santantonio D, Grace JC (1987) Estimating fine-root production and turnover from biomass and decomposition data: a compartment-flow model. Canadian Journal of Forest Research, 17, 900-908.

Silver WL, Herman DJ, Firestone MK (2001) Dissimilatory nitrate reduction to ammonium in tropical forest soils. Ecology, 82, 2410-2416.

Silver WL, Keller M, Lugo AE (1999) Soil oxygen availability and biogeochemical cycling along elevation and topographic gradients in Puerto Rico. Biogeochemistry, 44, 301-328.

Silver WL, Miya R (2001) Global patterns in root decomposition: comparisons of climate and litter quality effects. Oecologia, 129, 407-419.

Silver WL, Neff J, Veldkamp E et al. (2000) The effects of soil texture on belowground carbon and nutrient storage in a lowland Amazonian forest ecosystem. Ecosystems, 3, 193-209.
Silver WL, Vogt KA (1993) Fine root dynamics following single and multiple disturbances in a subtropical wet forest ecosystem. Journal of Ecology, 81, 729-738.

SPSS Inc. (2000) Systat Version 10. SPSS Inc., Chicago, IL.

Telles EDCC, de Camargo PB, Martinelli LA et al. (2003) Influence of soil texture on carbon dynamics and storage potential in tropical forest soils of Amazonia. Global Biogeochemical Cycles, 17, 1040-1051.

Trumbore SE, Salazar de Costa E, Nepstad DC et al. (2005) Dynamics of fine root carbon in Amazonian tropical ecosystems and the contribution of roots to soil respiration. Global Change Biology, in press.

Trumbore SE, Davidson EA, Barbosa de Camargo P et al. (1995) Belowground cycling of carbon in forests and pastures of Eastern Amazonia. Global Biogeochemical Cycles, 9, 515-528.

Varner RK, Keller M, Robertson JR et al. (2003) Experimentally induced root mortality increased nitrous oxide emission from tropical forest soils. Geophysical Research Letters, 30, 1141-1145.

Vitousek PM, Sanford RL (1986) Nutrient cycling in moist tropical forest. Annual Review of Ecology and Systematics, 17, 137-167.

Vogt KA, Grier CC, Vogt DJ (1986) Production, turnover, and nutrient dynamics in above-and belowground detritus of world forests. Advances in Ecological Research, 15, 303-377.

Vogt KA, Persson H (1991) Measuring growth and development of roots. In: Techniques and Approaches in Forest Tree Ecophysiology (eds Lassoie JP, Hinkley TM), pp. 447-502. CRC Press, Boca Raton, FL.

Vogt KA, Vogt DJ, Palmiotto PA et al. (1996) Review of root dynamics in forest ecosystems grouped by climate, climatic forest type and species. Plant and Soil, 187, 159-219. 